\title{
Sustainable microbial cell nanofactory for zinc oxide nanoparticles production by zinc-tolerant probiotic Lactobacillus plantarum strain TA4
}

\author{
Hidayat Mohd Yusof ${ }^{1}$, Rosfarizan Mohamad', Uswatun Hasanah Zaidan² and Nor'Aini Abdul Rahman ${ }^{1,3^{*}}$ (1)
}

\begin{abstract}
Background: The use of microorganisms in the biosynthesis of zinc oxide nanoparticles (ZnO NPs) has recently emerged as an alternative to chemical and physical methods due to its low-cost and eco-friendly method. Several lactic acid bacteria (LAB) have developed mechanisms in tolerating $Z n^{2+}$ through prevention against their toxicity and the production of ZnO NPs. The LAB's main resistance mechanism to $Z^{2+}$ is highly depended on the microorganisms' ability to interact with $\mathrm{Zn}^{2+}$ either through biosorption or bioaccumulation processes. Besides the inadequate studies conducted on biosynthesis with the use of zinc-tolerant probiotics, the understanding regarding the mechanism involved in this process is not clear. Therefore, this study determines the features of probiotic LAB strain TA4 related to its resistance to $\mathrm{Zn}^{2+}$. It also attempts to illustrate its potential in creating a sustainable microbial cell nanofactory of ZnO NPs.

Results: A zinc-tolerant probiotic strain TA4, which was isolated from local fermented food, was selected based on the principal component analysis (PCA) with the highest score of probiotic attributes. Based on the $16 \mathrm{~S}$ rRNA gene analysis, this strain was identified as Lactobacillus plantarum strain TA4, indicating its high resistance to $\mathrm{Zn}^{2+}$ at a maximum tolerable concentration (MTC) value of $500 \mathrm{mM}$ and its capability of producing ZnO NPs. The UV-visible spectroscopy analysis proved the formations of ZnO NPs through the notable absorption peak at $380 \mathrm{~nm}$. It was also found from the dynamic light scattering (DLS) analysis that the Z-average particle size amounted to $124.2 \mathrm{~nm}$ with monodisperse ZnO NPs. Studies on scanning electron microscope (SEM), energy-dispersive X-ray (EDX) spectroscopy, and Fourier-transform infrared spectroscopy (FT-IR) revealed that the main mechanisms in ZnO NPs biosynthesis were facilitated by the $\mathrm{Zn}^{2+}$ biosorption ability through the functional groups present on the cell surface of strain TA4.
\end{abstract}

Conclusions: The strong ability of zinc-tolerant probiotic of $L$. plantarum strain TA4 to tolerate high $\mathrm{Zn}^{2+}$ concentration and to produce ZnO NPs highlights the unique properties of these bacteria as a natural microbial cell nanofactory for a more sustainable and eco-friendly practice of ZnO NPs biosynthesis.

Keywords: Biological synthesis, Extracellular, FT-IR, Lactic acid bacteria, Lactobacillus plantarum, Probiotic, Zinctolerance, Zinc oxide nanoparticles

\footnotetext{
*Correspondence: nor_aini@upm.edu.my

${ }^{1}$ Department of Bioprocess Technology, Faculty of Biotechnology and Biomolecular Sciences, Universiti Putra Malaysia, 43400 Serdang, Selangor, Malaysia

Full list of author information is available at the end of the article
}

\section{Background}

Zinc oxide nanoparticles (ZnO NPs) have gained worldwide attention as multifunctional nanomaterials due to their distinctive properties of being versatile semiconductor and piezoelectric properties [1], which are

(c) The Author(s) 2020. This article is licensed under a Creative Commons Attribution 4.0 International License, which permits use, sharing, adaptation, distribution and reproduction in any medium or format, as long as you give appropriate credit to the original author(s) and the source, provide a link to the Creative Commons licence, and indicate if changes were made. The images or other third party material in this article are included in the article's Creative Commons licence, unless indicated otherwise in a credit line to the material. If material is not included in the article's Creative Commons licence and your intended use is not permitted by statutory regulation or exceeds the permitted use, you will need to obtain permission directly from the copyright holder. To view a copy of this licence, visit http://creativeco mmons.org/licenses/by/4.0/. The Creative Commons Public Domain Dedication waiver (http://creativecommons.org/publicdomain/ zero/1.0/) applies to the data made available in this article, unless otherwise stated in a credit line to the data. 
different than their bulkier counterparts. Recently, $\mathrm{ZnO}$ NPs are utilized in various applications, such as pharmaceuticals [2], cosmetics [3], photocatalysis [4], and dietary supplement for animals [5]. Many chemical methods are proposed for the synthesis of $\mathrm{ZnO}$ NPs, including sol-gel process, solvent evaporation and precipitation from microemulsion [6]. However, the methods are not environmentally-friendly due to the use of harsh chemicals for reduction and stabilizing processes, which will bind to the ZnO NPs, and limit their biological application [5]. Moreover, these process also contribute to secondary pollution by generating toxic by-products. Hence, the development of more sustainable approaches in preparing ZnO NPs are emphasized and in-depth studies are conducted to replace the conventional methods.

Recently, microbial synthesis of metal nanoparticles (NPs) is widely employed due to the low cost, biocompatibility, and being eco-friendly [5]. A number of microorganisms, including bacteria, fungi and yeast are investigated due to their efficiency in $\mathrm{Zn}^{2+}$ sorption and $\mathrm{ZnO}$ NPs synthesis. Bacteria such as Lactobacillus produce $\mathrm{ZnO}$ NPs intracellularly [7]. Meanwhile, fungi and yeast such as Aspergillus aeneus and Pichia fermentans, respectively, produce $\mathrm{ZnO}$ NPs extracellularly $[8,9]$. Among the microorganisms, lactic acid bacteria (LAB) receive significant attention due to their safety in handling and food-grade status, which are "generally recognized as safe" (GRAS) in food production and preservation. In addition, some LAB strains exhibit probiotic properties for human and animal consumption, contributing to health-promoting properties [10].

Furthermore, LAB efficacy in mediating the synthesis of $\mathrm{ZnO}$ NPs was observed in several studies [6, 9-12]. It was reported that LAB can produce selenium [13], gold [14], and silver NPs [15]. Overall, LAB is a useful cell factory for the formation of NPs due to these features. As Gram-positive bacteria, LAB have a thick cell wall consisting of peptidoglycan, lipoteichoic acid, protein, and polysaccharides [16]. The layers function as the sites for the biosorption and bioreduction of metal ions, due to their negative electrokinetic potential features, which attract the metal cations to initiate NPs biosynthesis [7]. Former study by Król et al. [7] proposed that the deprotonated carboxyl groups (functional group) present on the cell surface of $L$. paracasei strain interact with the zincaqua complexes (electron acceptor) to form $\mathrm{ZnO}$ NPs. Also, LAB produce a wide range of exopolysaccharides (EPS) [17], which serve as the additional binding sites for the cationic metal ions and protect the microorganisms from toxic metal stresses [18].

It is suggested that the biosynthesis of metal or metal oxide NPs is influenced by the microorganisms' ability to tolerate with metal ion. In fact, high metal stresses affect microbial activity. Under this condition, the microorganisms will interact with metal ions and reduce them to nanoscale metal particles [17, 18]. This interaction enables microorganisms to act as microbial nanofactory. Bacteria adopt several strategies to encounter the toxicity of metal ions via metal ion biosorption and bioaccumulation. Biosorption is a passive and non-metabolically mediated process that involves binding, ion exchange, chelation and precipitation, which depend on the presence of functional groups on the bacterial cell walls [19-21]. This is followed by bioaccumulation, in which the metal ions will enter into the cell and react with bacterial intracellular structures [20, 22]. Figure 1 proposed the mechanisms of Gram-positive bacteria in resisting metal ion and reducing it to the respective metal NPs.

A number of metal-tolerant microorganisms have been isolated from various ecological niches $[7,23]$ to recover metal NPs. However, the studies conducted on zinc-tolerant probiotic in the biosynthesis of $\mathrm{ZnO}$ NPs are limited. Over the last decades, there is heavy usage of probiotic due to its ability to tolerate and bind to various metal ions such as copper $(\mathrm{Cu})$ [24], arsenic (As) [25], zinc (Zn) [19], cadmium (Cd) [21, 22], selenium $(\mathrm{Se})$, and lead $(\mathrm{Pb})[26,27]$ for toxicological and environmental purposes. However, there has been no proper explanation regarding the mechanisms in which this microorganism resists to $\mathrm{Zn}^{2+}$ and produces $\mathrm{ZnO}$ NPs simultaneously. Furthermore, the use of probiotic LAB contributes to many benefits, due to the nonpathogenic property, simplicity, and abundance in food products. The metal-tolerant LAB-based probiotic can be the food-grade $\mathrm{ZnO}$ NPs producer and adopted as dietary strategy. This is applicable in heavy metal decontamination in the gastrointestinal tract (GIT) of humans and animals, which are exposed to high metal content.

Putting the high number of LAB structures and metabolic features into consideration, diverse outcomes could be predicted in the mechanisms of NPs formation. Therefore, this study aims to investigate the potential of zinctolerant LAB equipped with probiotic properties to be utilized as microbial nanofactory for more sustainable productions of $\mathrm{ZnO}$ NPs. In this study, the zinc-tolerant probiotic was isolated from locally fermented food, which is capable to resist high $\mathrm{Zn}^{2+}$ concentration and produce $\mathrm{ZnO}$ NPs. The biosynthesized ZnO NPs were validated and characterized by UV-visible spectroscopy and dynamic light scattering (DLS). The underlying mechanisms of $\mathrm{ZnO}$ NPs formation were scrutinized using scanning electron microscope (SEM), energy-dispersive X-ray (EDX) spectroscopy, and Fourier-transform infrared spectroscopy (FT-IR). 


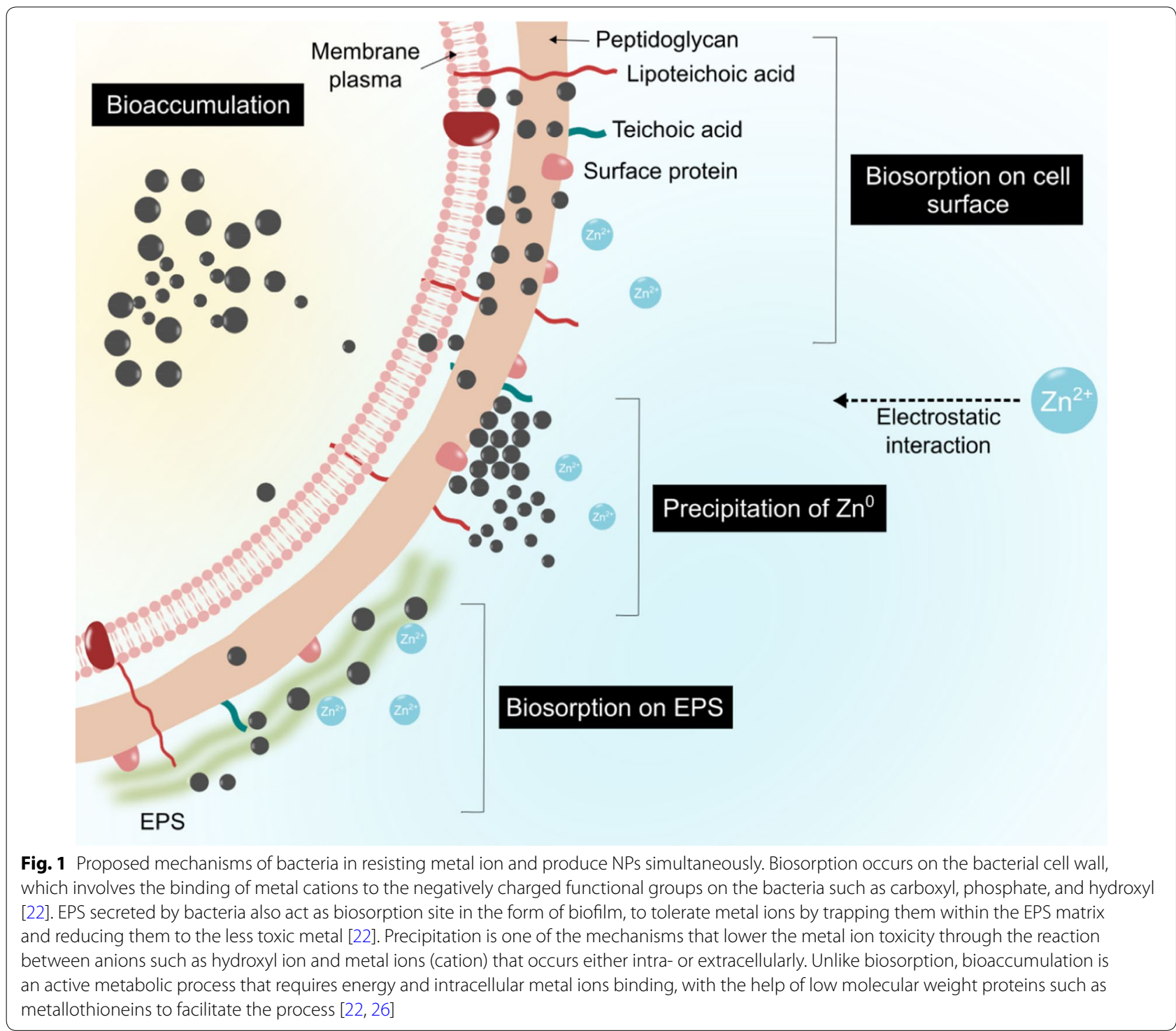

\section{Results}

\section{Isolation and morphological characterization}

A total of 125 LAB strains from different sources were obtained. All strains were Gram-positive cocci and bacilli with the catalase-negative trait. All the strains were used for zinc tolerance pre-screening. Eighteen (14.4\%) strains were able to grow in the presence of $10 \mathrm{mM} \mathrm{Zn}^{2+}$. All of the potential strains were Gram-positive and rod-shaped. The colony morphologies of the strains were whitish cream and circular and the strains were identified as Lactobacillus.

The maximum tolerable concentration (MTC) of LAB strains The maximum tolerable concentration (MTC) values of the LAB strains are presented in Table 1. The MTC of the
$18 \mathrm{LAB}$ strains were investigated to determine the ability of the bacteria to tolerate various concentrations of $\mathrm{Zn}^{2+}$. Out of 18 LAB strains, four strains (TA4, SC8, FF2, and MPJ10) exhibited the highest MTC values at $500 \mathrm{mM}$. Figure 2a depicts the MTC assay using agar well diffusion method, which showed different levels of tolerance by the $\mathrm{LAB}$ strains against various $\mathrm{Zn}^{2+}$ concentrations. Nevertheless, the agar well diffusion method was unable to determine the viability of the surviving cell; hence, the tube dilution method was performed to measure the number of propagating LAB in different $\mathrm{Zn}^{2+}$ concentrations. Based on the presented results in Fig. 2b, the ability of each strain was varied in various concentrations and interestingly, strain TA4 demonstrated a remarkable growth at the highest concentration of $\mathrm{Zn}^{2+}$, which 
Table 1 Zinc tolerance of the LAB strains against different zinc concentrations

\begin{tabular}{|c|c|c|c|c|c|c|c|c|c|c|}
\hline \multirow[t]{3}{*}{ Strain code } & \multicolumn{10}{|c|}{ Inhibition zone (mm) } \\
\hline & \multicolumn{10}{|c|}{$\mathrm{Zn}^{2+}$ concentration $(\mathrm{mM})$} \\
\hline & 20 & 40 & 60 & 80 & 100 & 200 & 300 & 400 & 500 & 600 \\
\hline $\mathrm{TA}^{\mathrm{a}}$ & $\mathrm{R}(-)$ & $\mathrm{R}(-)$ & $\mathrm{R}(-)$ & $\mathrm{R}(-)$ & $\mathrm{R}(-)$ & $\mathrm{R}(-)$ & $\mathrm{R}(-)$ & $R(0.5)$ & $R(1)$ & $S(1.2)$ \\
\hline TP2 & $\mathrm{R}(-)$ & $\mathrm{R}(-)$ & $\mathrm{R}(-)$ & $\mathrm{R}(-)$ & $R(0.5)$ & $S(2)$ & $S(3)$ & $S(4)$ & $S(4.5)$ & $S(6)$ \\
\hline TP6 & $\mathrm{R}(-)$ & $\mathrm{R}(-)$ & $\mathrm{R}(-)$ & $\mathrm{R}(-)$ & $\mathrm{R}(-)$ & $S(2)$ & $S(4)$ & $S(4)$ & $S(4)$ & $S(5)$ \\
\hline SC2 & $R(-)$ & $\mathrm{R}(-)$ & $\mathrm{R}(-)$ & $R(1)$ & $R(1)$ & $S(1.5)$ & $S(3)$ & $S(4)$ & $S(4.5)$ & $S(6)$ \\
\hline SC4 & $\mathrm{R}(-)$ & $R(0.5)$ & $R(0.5)$ & $R(1)$ & $\mathrm{R}(1)$ & $S(2)$ & $S(3)$ & $S(4)$ & $S(4.5)$ & $\mathrm{S}(5)$ \\
\hline SC7 & $R(-)$ & $\mathrm{R}(-)$ & $\mathrm{R}(-)$ & $\mathrm{R}(-)$ & $\mathrm{R}(-)$ & $R(1)$ & $S(2)$ & $S(2)$ & $S(3)$ & $S(4.5)$ \\
\hline $\mathrm{SC} 8^{\mathrm{a}}$ & $R(-)$ & $\mathrm{R}(-)$ & $\mathrm{R}(-)$ & $\mathrm{R}(-)$ & $\mathrm{R}(-)$ & $R(0.5)$ & $R(0.5)$ & $R(1)$ & $R(1)$ & $S(1.5)$ \\
\hline MP3 & $\mathrm{R}(-)$ & $\mathrm{R}(-)$ & $\mathrm{R}(-)$ & $R(0.5)$ & $R(0.5)$ & $S(2)$ & $S(2)$ & $S(2)$ & $S(3)$ & $S(4)$ \\
\hline MP6 & $\mathrm{R}(-)$ & $\mathrm{R}(-)$ & $R(0.5)$ & $R(1)$ & $\mathrm{R}(1)$ & $S(2)$ & $S(4)$ & $S(4.5)$ & $S(4.5)$ & $S(5)$ \\
\hline $\mathrm{FF} 2^{\mathrm{a}}$ & $R(-)$ & $\mathrm{R}(-)$ & $\mathrm{R}(-)$ & $\mathrm{R}(-)$ & $\mathrm{R}(-)$ & $\mathrm{R}(-)$ & $\mathrm{R}(1)$ & $R(1)$ & $R(1)$ & $S(2)$ \\
\hline FF4 & $\mathrm{R}(-)$ & $\mathrm{R}(-)$ & $\mathrm{R}(-)$ & $\mathrm{R}(-)$ & $\mathrm{R}(-)$ & $S(2)$ & $S(2.5)$ & $S(3)$ & $S(3)$ & $S(4)$ \\
\hline MPJ1 & $\mathrm{R}(-)$ & $\mathrm{R}(-)$ & $\mathrm{R}(-)$ & $\mathrm{R}(-)$ & $\mathrm{R}(-)$ & $S(2)$ & $S(3)$ & $S(3.5)$ & $S(4)$ & $S(6)$ \\
\hline MPJ2 & $\mathrm{R}(-)$ & $\mathrm{R}(-)$ & $\mathrm{R}(-)$ & $\mathrm{R}(-)$ & $\mathrm{R}(-)$ & $S(1.5)$ & $S(2)$ & $S(3)$ & $S(5)$ & $S(5)$ \\
\hline MPJ4 & $\mathrm{R}(-)$ & $\mathrm{R}(-)$ & $\mathrm{R}(-)$ & $\mathrm{R}(-)$ & $\mathrm{R}(-)$ & $S(2)$ & $S(2)$ & $S(3)$ & $S(4)$ & $S(5)$ \\
\hline MPJ5 & $\mathrm{R}(-)$ & $\mathrm{R}(-)$ & $R(0.5)$ & $R(0.5)$ & $R(1)$ & $S(2)$ & $S(3)$ & $S(5)$ & $S(5)$ & $S(5.5)$ \\
\hline MPJ7 & $\mathrm{R}(-)$ & $\mathrm{R}(-)$ & $\mathrm{R}(-)$ & $\mathrm{R}(-)$ & $\mathrm{R}(-)$ & $S(2.5)$ & $S(3)$ & $S(4)$ & $S(5)$ & $S(5)$ \\
\hline MPJ9 & $R(-)$ & $\mathrm{R}(-)$ & $\mathrm{R}(-)$ & $\mathrm{R}(-)$ & $\mathrm{R}(-)$ & $S(2)$ & $S(2.5)$ & $S(2.5)$ & $S(4)$ & $S(5)$ \\
\hline MPJ10 & $R(-)$ & $\mathrm{R}(-)$ & $\mathrm{R}(-)$ & $\mathrm{R}(-)$ & $\mathrm{R}(-)$ & $R(0.5)$ & $R(0.5)$ & $R(1)$ & $R(1)$ & $S(2)$ \\
\hline
\end{tabular}

The results of the inhibition zone are shown in parenthesis

$S$ sensitive ( $\geq 1.5 \mathrm{~mm}), R$ resistant $(\leq 1 \mathrm{~mm}$ )

a Indicating the strains that exhibited the highest MTC value

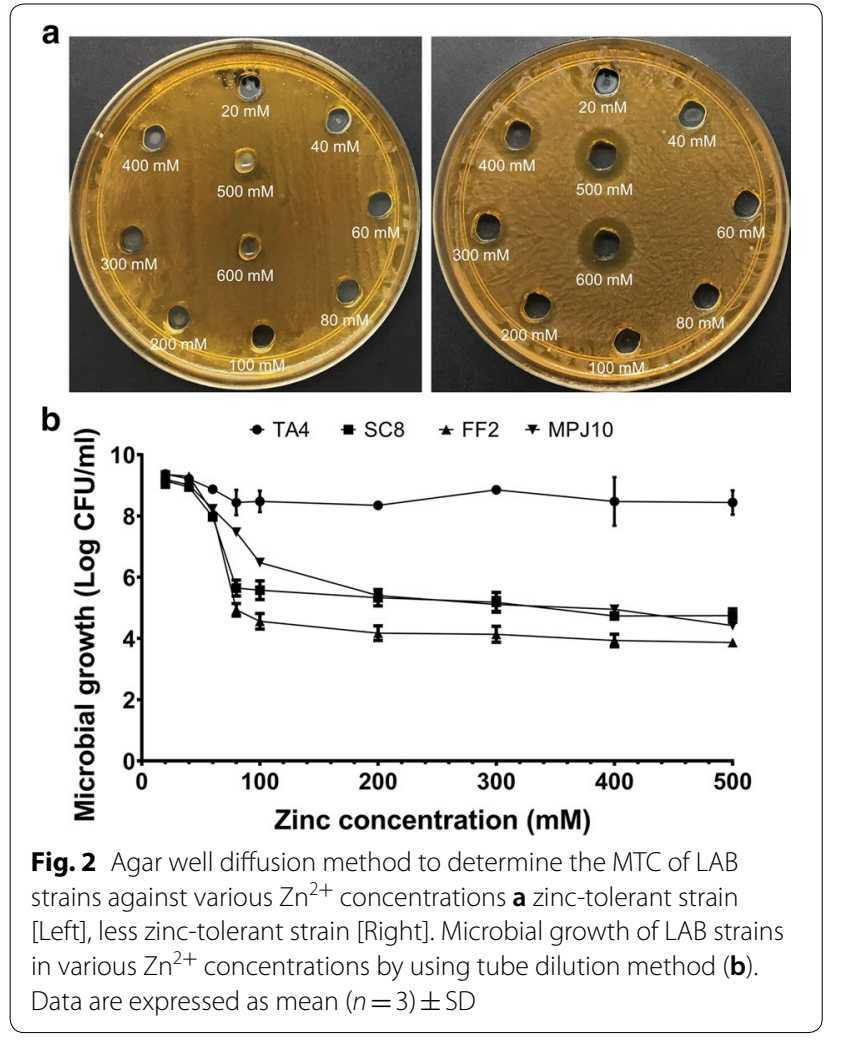

was only a onefold reduction of growth $(\log \mathrm{CFU} / \mathrm{mL})$. Meanwhile, other strains showed up to four- to fivefold reduction of growth with increasing $\mathrm{Zn}^{2+}$ concentration, starting from a concentration of $80 \mathrm{mM}$. However, at those particular $\mathrm{Zn}^{2+}$ concentrations, the strains were still able to propagate and survive, which indicate their tolerance against $\mathrm{Zn}^{2+}$. Therefore, strains TA4, SC8, FF2, and MPJ10 were selected for further screening of their probiotic attributes.

\section{In vitro probiotic characterization of zinc-tolerant $L A B$ Acidic $\mathrm{pH}$, bile salts, and phenol tolerance}

Resistance to gastric $\mathrm{pH}$, bile, and phenol are key features for bacteria to be able to survive in the gastrointestinal tract (GIT) and are some of the important selection criteria for probiotic. As shown in Table 2, all the strains survived at $\mathrm{pH} 2.5$ and 3.5. The maximum survival rate percentage was at $\mathrm{pH} 3.5$ ranging from 90.5 to $94.3 \%$, with strain MPJ10 exhibiting the highest value. Meanwhile, at $\mathrm{pH} 2.5$, all the strains showed various survival rates ranging from 59.9 to $85.1 \%$, with strain FF2 exhibiting the highest percentage value and strain SC8 exhibiting the lowest value. However, no significance difference $(p>0.05)$ in survival rate percentage was observed in both tested $\mathrm{pH}$ among the strains, which indicate that all 
Table 2 Tolerance of the strains to acidic $\mathrm{pH}$ and bile salts at $37^{\circ} \mathrm{C}$ for 0 and $4 \mathrm{~h}(\log \mathrm{CFU} / \mathrm{mL})$

\begin{tabular}{|c|c|c|c|c|c|c|c|c|c|c|c|c|}
\hline \multirow[t]{3}{*}{ Strain } & \multicolumn{6}{|l|}{$\mathrm{pH}$} & \multicolumn{6}{|l|}{ Bile } \\
\hline & \multicolumn{3}{|l|}{2.5} & \multicolumn{3}{|l|}{3.5} & \multicolumn{3}{|l|}{$0.3 \%$} & \multicolumn{3}{|l|}{$0.6 \%$} \\
\hline & $\mathrm{Oh}$ & $4 \mathrm{~h}$ & SR \% & $\mathrm{Oh}$ & $4 \mathrm{~h}$ & SR \% & $\mathrm{Oh}$ & $4 \mathrm{~h}$ & SR \% & $\mathrm{Oh}$ & $4 \mathrm{~h}$ & SR \% \\
\hline TA4 & $9.22 \pm 0.04$ & $9.12 \pm 0.01$ & $79^{a}$ & $9.36 \pm 0.02$ & $9.32 \pm 0.06$ & $90.5^{\mathrm{a}}$ & $8.93 \pm 0.07$ & $8.85 \pm 0.11$ & $83.2^{\mathrm{a}}$ & $9.06 \pm 0.17$ & $9.01 \pm 0.19$ & $88.5^{\mathrm{a}}$ \\
\hline SC8 & $9.23 \pm 0.05$ & $9.00 \pm 0.07$ & $59.9^{a}$ & $9.24 \pm 0.07$ & $9.20 \pm 0.10$ & $91.5^{\mathrm{a}}$ & $9.05 \pm 0.18$ & $8.95 \pm 0.05$ & $81.5^{\mathrm{a}}$ & $9.05 \pm 0.15$ & $9.00 \pm 0.14$ & $90.3^{\mathrm{a}}$ \\
\hline FF2 & $9.24 \pm 0.02$ & $9.16 \pm 0.11$ & $85.1^{\mathrm{a}}$ & $8.98 \pm 0.05$ & $8.95 \pm 0.08$ & $91.8^{\mathrm{a}}$ & $9.02 \pm 0.02$ & $8.91 \pm 0.05$ & $78.1^{\mathrm{a}}$ & $8.72 \pm 0.03$ & $8.67 \pm 0.11$ & $88.1^{\mathrm{a}}$ \\
\hline MPJ10 & $9.35 \pm 0.07$ & $9.20 \pm 0.11$ & $70.4^{\mathrm{a}}$ & $9.22 \pm 0.05$ & $9.20 \pm 0.05$ & $94.3^{\mathrm{a}}$ & $9.02 \pm 0.04$ & $8.97 \pm 0.04$ & $89.9^{\mathrm{a}}$ & $8.75 \pm 0.09$ & $8.64 \pm 0.04$ & $76.7^{\mathrm{a}}$ \\
\hline
\end{tabular}

The results are expressed as mean $(n=3) \pm$ SD, and values within the same column with different superscript letters indicate statistical differences in each strain according to Tukey's test at $p<0.05$. The means are presented as log-transformed values of CFU $/ \mathrm{mL}$ of the strains

SR\% survival rate percentage

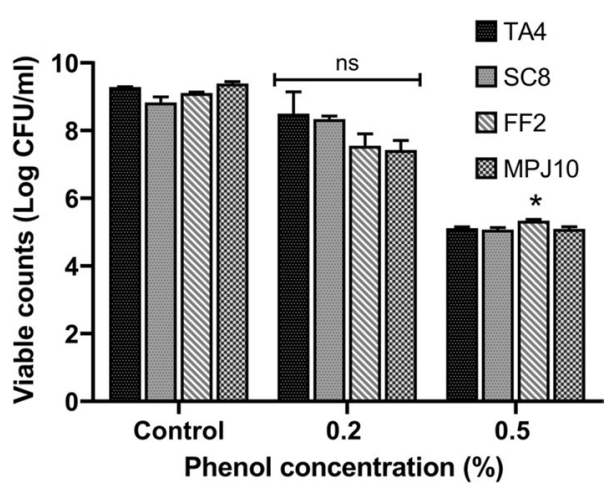

Fig. 3 Phenol tolerance of all strains at concentration of 0.2 and $0.5 \%$ (v/v). The culture was incubated at $37 \mathrm{C}$ for $24 \mathrm{~h}$. Data are expressed as mean $(n=3) \pm S D$. ${ }^{*} p<0.05$. ns no significant

strains are able to survive in acidic $\mathrm{pH}$ for $4 \mathrm{~h}$. A similar trend was seen in bile tolerance ability, where there was a high survival rate percentage among the strains at bile concentrations of $0.3 \%$ and $0.6 \%$ ranging from 78.1 to $89.9 \%$ and 76.7 to $90.3 \%$, respectively. For phenol tolerance (Fig. 3), all the strains showed the ability to grow under a phenol concentration of $0.2 \%$, whereas at a concentration of $0.5 \%$, the viable counts $(\log \mathrm{CFU} / \mathrm{mL})$ for all strains decreased.

\section{Cell surface hydrophobicity, cellular autoaggregation assessment and EPS production}

The adhesion characteristics of all the strains is shown in Table 3. Strains TA4 and SC8 demonstrated hydrophobic characteristics with $58 \%$ and $56.1 \%$ adhering to toluene, which is an apolar solvent. Meanwhile, strains FF2 and MPJ10 showed the lowest percentage indicated their hydrophilic characteristics. For chloroform, strains TA4 and SC8 showed the highest percentage with 54.9\% and $54.5 \%$, respectively, whereas strain MPJ10 demonstrated the highest hydrophobic percentage to ethyl acetate with $53.6 \%$. Results for cellular autoaggregation are presented in Table 3 . For all the four potential probiotics, the ability to autoaggregate increased by augmenting the incubation time. Among the strains, strain TA4 exhibited the highest value $(64 \%)$ at $4 \mathrm{~h}$ and all strains showed the highest values after $24 \mathrm{~h}$ incubation in the range of 64.4-99.3\%. For EPS production, none of the strains showed positive results for EPS production.

\section{Antimicrobial activity}

The antagonistic properties of the LAB strains against Gram-negative and Gram-positive pathogens are presented in Table 4. The non-neutralized CFS of all strains were subjected against indicator pathogens E. coli, Salmonella sp., S. aureus, and S. epidermidis.

Table 3 Cell surface hydrophobicity activity of LAB strains against different solvents and cellular autoaggregation activity at a different time of incubation and EPS production ability

\begin{tabular}{|c|c|c|c|c|c|c|c|}
\hline \multirow[t]{2}{*}{ Strain } & \multicolumn{3}{|c|}{ Cell surface hydrophobicity (\%) } & \multicolumn{3}{|c|}{ Cellular autoaggregation (\%) } & \multirow{2}{*}{$\begin{array}{l}\text { EPS } \\
\text { production }\end{array}$} \\
\hline & Chloroform & Toluene & Ethyl acetate & $1 \mathrm{~h}$ & $4 \mathrm{~h}$ & $24 \mathrm{~h}$ & \\
\hline TA4 & $54.93 \pm 0.34^{\mathrm{a}}$ & $57.99 \pm 1.04^{\mathrm{a}}$ & $41.36 \pm 1.18^{c}$ & $6.14 \pm 0.05^{a b}$ & $64.00 \pm 0.01^{\mathrm{a}}$ & $99.33 \pm 0.03^{\mathrm{a}}$ & - \\
\hline SC8 & $54.49 \pm 0.16^{\mathrm{a}}$ & $56.05 \pm 0.00^{\mathrm{a}}$ & $44.40 \pm 0.10^{b}$ & $3.64 \pm 0.00^{c}$ & $11.93 \pm 0.27^{c}$ & $88.69 \pm 0.09^{c}$ & - \\
\hline FF2 & $28.51 \pm 3.51^{c}$ & $26.87 \pm 0.08^{b}$ & $35.47 \pm 0.41^{d}$ & $4.91 \pm 0.57^{b c}$ & $14.60 \pm 0.20^{b}$ & $98.03 \pm 0.02^{b}$ & - \\
\hline MPJ10 & $40.94 \pm 0.80^{b}$ & $11.41 \pm 2.08^{c}$ & $53.55 \pm 0.64^{\mathrm{a}}$ & $1.95 \pm 0.57^{d}$ & $13.62 \pm 0.54^{b}$ & $64.39 \pm 0.19^{d}$ & - \\
\hline
\end{tabular}

The results are expressed as mean $(n=3) \pm$ SD, and values within the same column with different superscript letters indicate statistical differences in each strain according to Tukey's test at $p<0.05$ 
Table 4 Antibacterial activity of cell-free supernatant (CFS) of the LAB strains

\begin{tabular}{|c|c|c|c|c|c|}
\hline \multirow[t]{3}{*}{ Strain } & \multirow[t]{3}{*}{ Final pH of CFS } & \multicolumn{4}{|c|}{ Zone of inhibition $(\mathrm{mm})$} \\
\hline & & \multicolumn{2}{|c|}{ Gram-negative } & \multicolumn{2}{|l|}{ Gram-positive } \\
\hline & & E. coli & Salmonella sp. & S. aureus & S. epidermidis \\
\hline TA4 & $3.41 \pm 0.05$ & $19.33 \pm 0.58^{\mathrm{a}}$ & $16.67 \pm 1.15^{b}$ & $19.00 \pm 1.00^{\mathrm{a}}$ & $17.67 \pm 0.58^{\mathrm{a}}$ \\
\hline SC8 & $3.85 \pm 0.14$ & $19.00 \pm 1.00^{\mathrm{a}}$ & $20.00 \pm 0.00^{\mathrm{a}}$ & $13.00 \pm 0.00^{b}$ & $11.00 \pm 0.00^{c}$ \\
\hline FF2 & $3.48 \pm 0.03$ & $18.33 \pm 0.58^{\mathrm{a}}$ & $15.00 \pm 1.00^{b}$ & $18.67 \pm 0.58^{\mathrm{a}}$ & $16.00 \pm 1.00^{\mathrm{ab}}$ \\
\hline MPJ10 & $3.36 \pm 0.03$ & $18.00 \pm 0.00^{\mathrm{a}}$ & $15.00 \pm 0.00^{b}$ & $17.67 \pm 0.58^{\mathrm{a}}$ & $15.00 \pm 1.00^{b}$ \\
\hline
\end{tabular}

The results are expressed as mean $(n=3) \pm S D$, and values within the same column with different superscript letters indicate statistical differences in each strain according to Tukey's test at $p<0.05$

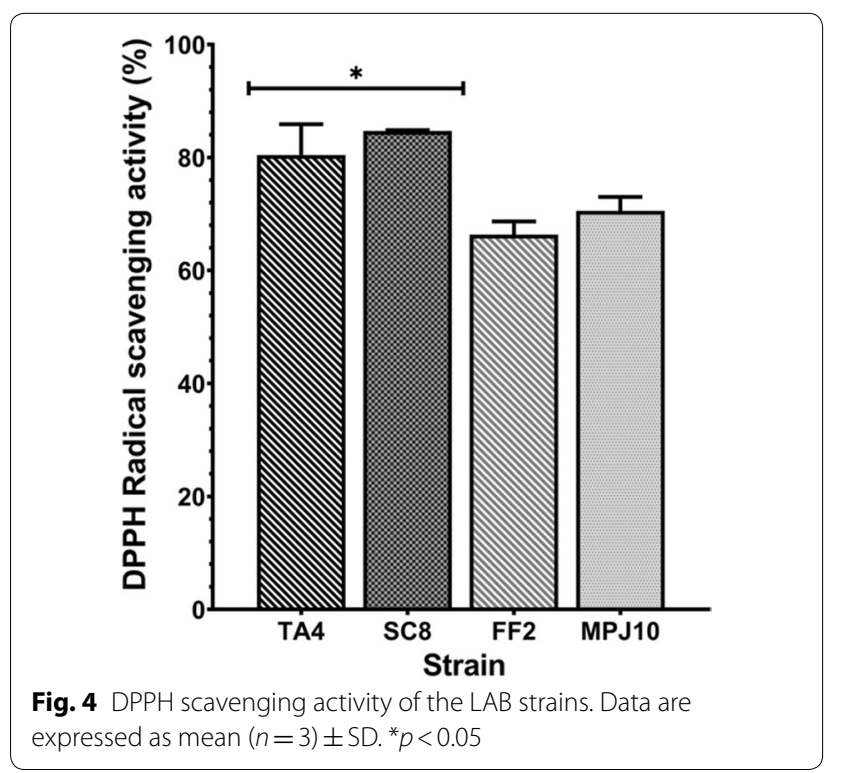

Strains TA4, FF2, and MPJ10 demonstrated antagonism against the tested pathogens. Meanwhile, strain SC8 showed high antagonism against E. coli and Salmonella and least antagonism activity was detected on S. aureus and S. epidermidis. Moreover, the neutralized CFS of all strains did not show any inhibitory activity against the tested pathogens (data not shown).

\section{2,2-Diphenyl-1-picrylhydrazyl (DPPH) free radical scavenging activity (RSA)}

DPPH free radical-scavenging activity of LAB strains is illustrated in Fig. 4. The cell-free supernatant (CFS) of strains SC8 and TA4 exhibited high antioxidant activity at $84.7 \%$ and $80.5 \%(p<0.05)$, respectively, while strains FF2 and MPJ10 showed the least antioxidant activity with $66.3 \%$ and $70.5 \%$, respectively.

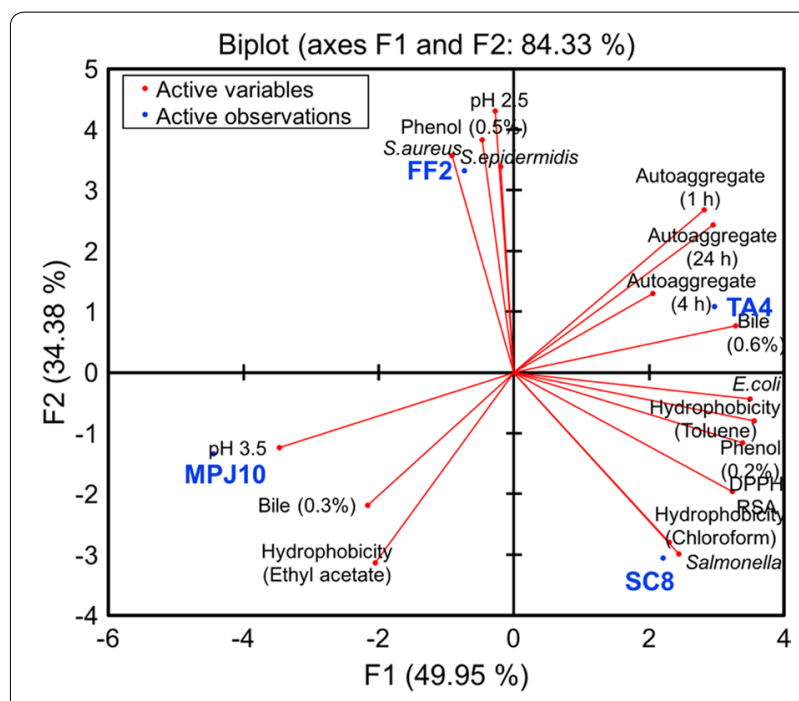

Fig. 5 Principal component analysis (PCA) biplot projection based on probiotic attributes for selection of potential probiotic LAB strains. The principal components explain $84.33 \%$ of the total variance

\section{Principal component analysis (PCA)}

Principal component analysis (PCA) was conducted to identify the promising $\mathrm{LAB}$ probiotic by investigating the correlation amongst the probiotic attributes, which were $\mathrm{pH}$, bile, phenol tolerance, cell surface hydrophobicity, cellular autoaggregation, antimicrobial activity, and antioxidant activity (Fig. 5). PCA is designated with two principal components where the first principal component (F1) represents the maximum variation in the data and the second principal component (F2) covers the remaining variation to the first. Based on the analysis, the two principal components (F1 and F2) explained $84.33 \%$ of the total variation, while F1 and F2 accounted for 49.95\% and $34.38 \%$ variance in the data, respectively (Fig. 5 ). The PCA revealed that the factorial space can be classified into four major groups in which the first group consists of strain TA4, which is located in quadrant I (positive side of both F1 and F2) and expressed the highest value 
for autoaggregation and bile tolerance attributes. The second group consists of strain FF2 located in quadrant II (positive side of F2 and negative side of F1), which exhibited high values for $\mathrm{pH}$, phenol tolerance, and antimicrobial activity. The third group consists of strain MPJ10 located at quadrant III (negative side for both F1 and F2) and expressed high values for $\mathrm{pH}$, bile, and hydrophobicity. The fourth group consists of strain SC8 located at quadrant IV (positive side of F1 and the negative side of F2), which expressed high values for phenol tolerance, antioxidant and antimicrobial activity, and hydrophobicity. In general, strains TA4 and SC8 possessed the highest levels of probiotic properties. In particular, strain TA4 showed the highest correlation with respect to variables with maximum factor scores (Table 5), clearly proving it as a probiotic candidate with the highest potential. Thus, strain TA4 was selected as a zinc-tolerant probiotic for microbial synthesis of $\mathrm{ZnO}$ NPs.

\section{Sequence analysis of the $16 \mathrm{~S}$ rRNA gene}

16S rRNA gene analysis of strain TA4 (1489 bp) revealed the highest degree of similarities to Lactobacillus plantarum CIP 103151 (100\%), followed by L. pentosus 124-2

Table 5 Factor score of principal component (F1-F3) for potential probiotic strains

\begin{tabular}{lrrr}
\hline Observation & F1 & F2 & \multicolumn{1}{c}{ F3 } \\
\hline TA4 & 2.967 & 1.080 & 2.168 \\
SC8 & 2.208 & -3.059 & -1.483 \\
FF2 & -0.730 & 3.324 & -1.670 \\
MPJ10 & -4.445 & -1.344 & 0.985 \\
\hline
\end{tabular}

(100\%), L. plantarum JCM 1149 (99.87\%), L. paraplantarum DSM 10667 (99.8\%), and L. plantarum NBRC 15891 (99.93\%). Based on the phylogenetic relationship analysis using the neighbor-joining method (Fig. 6), strain TA4 was placed next to L. plantarum. Moreover, strain TA4 is Gram-positive and rod-shaped and form circular and creamy white colonies on MRS agar. Morphological and microscopic observation of strain TA4 together with the phylogenetic analysis revealed that the strain TA4 was tentatively identified as L. plantarum strain TA4. The 16S rRNA sequence of this strain has been deposited to the GenBank under the Accession number of MN122698.

\section{Characterization of biosynthesized ZnO NPs UV-vis spectroscopy and dynamic light scattering (DLS)}

The optical properties of ZnO NPs are essential aspects of the structure and feature characterization. The absorption peak of biosynthesized $\mathrm{ZnO}$ NPs showed maximum surface plasmon resonance (SPR) bands at the wavelength of $380 \mathrm{~nm}$ (Fig. 7a), which confirmed the formation of $\mathrm{ZnO}$ NPs. One of the standard methods to measure the average diameter of NPs in a colloid solution is by using dynamic light scattering (DLS). Laser diffraction revealed that the average hydrodynamic size of NPs obtained was $124.2 \pm 31.2 \mathrm{~nm}$ along with the polydispersity index (PDI) of 0.369 (Fig. 7b), indicating monodispersed NPs.

\section{Scanning electron microscope (SEM) and energy dispersive $X$-ray (EDX) analysis}

To study the effect of $\mathrm{Zn}^{2+}$ exposure on cellular morphology of TA4 strain, scanning electron microscope (SEM) was performed. The micrographs obtained

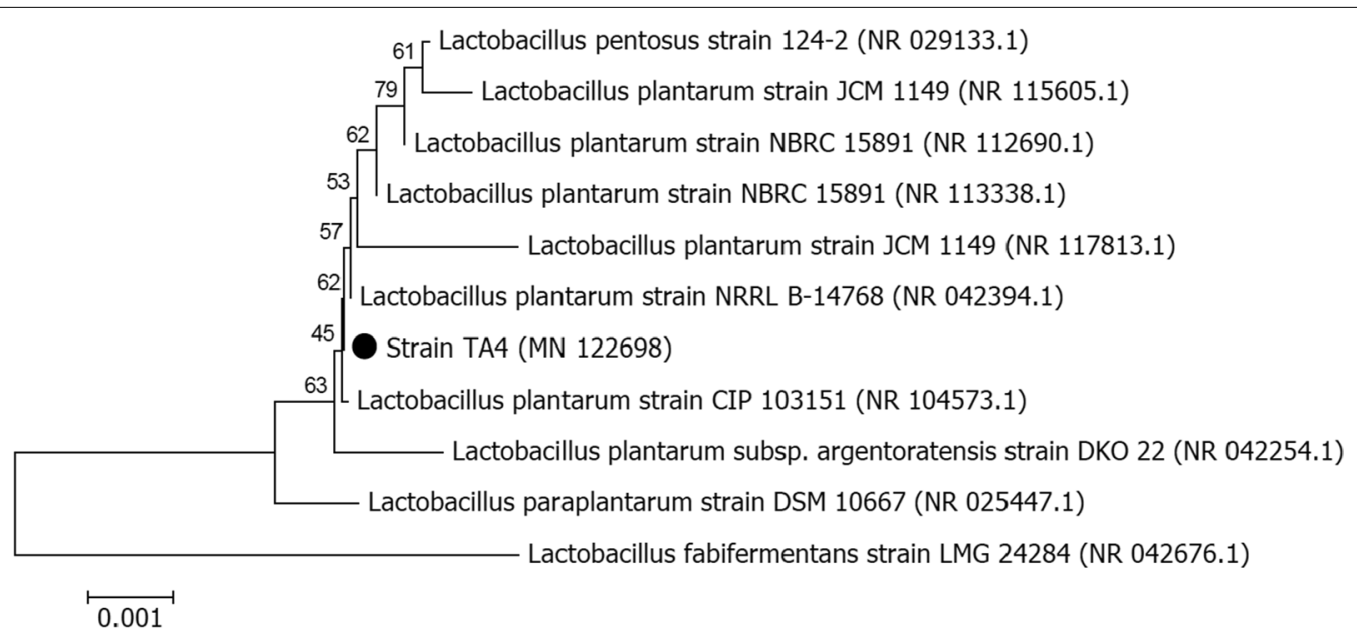

Fig. 6 Phylogenetic tree of L. plantarum strain TA4. The tree is drawn to scale, with branch lengths in the same units as those of the evolutionary distances used to infer the phylogenetic tree. The analysis involved 11 nucleotide sequences 


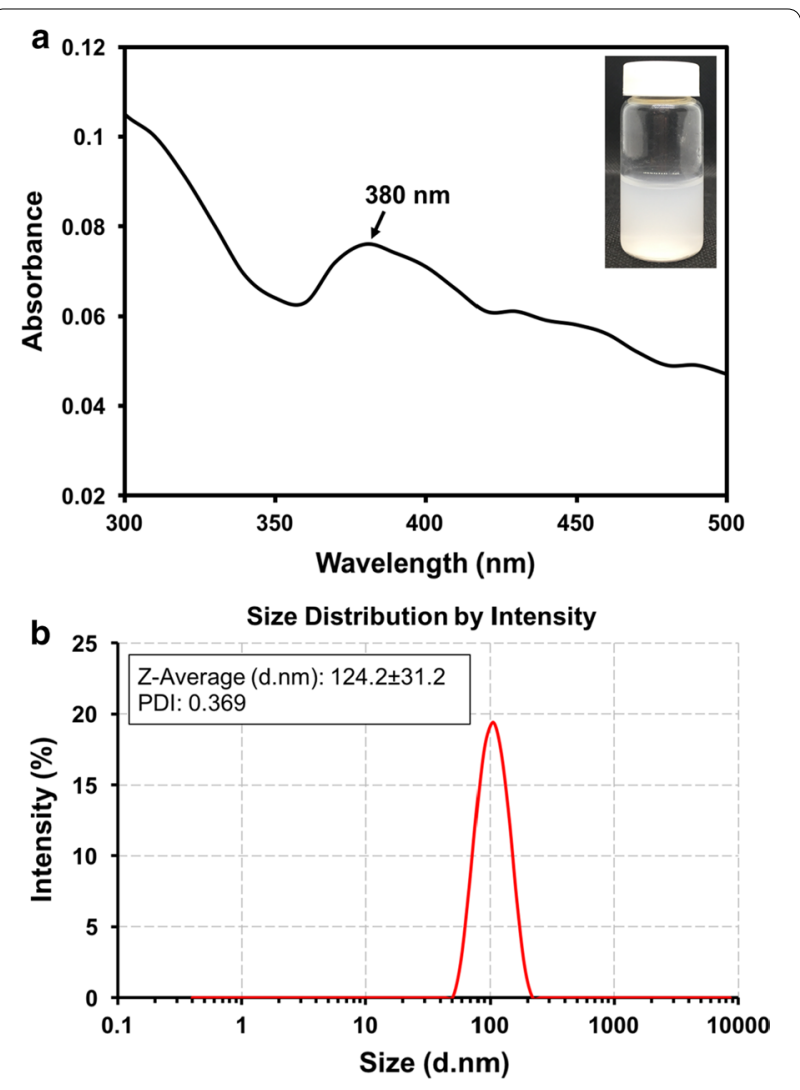

Fig. 7 UV-vis absorption spectrum of biosynthesized ZnO NPs by L. plantarum strain TA4 cell biomass exposed to $\mathrm{Zn}^{2+}$. a Particle size distribution as obtained from DLS of biosynthesized ZnO NPs by $L$. plantarum strain TA4 (b) showed different changes in cell morphology of TA4 strain. The cells of the control group (Fig. 8a) exhibited smooth-surface and typically healthy rod-shaped of TA4 strain. In contrast, under the exposure of $\mathrm{Zn}^{2+}$, significant alteration in terms of cell membrane conformation is observed compared to the control, where the TA4 strain is no longer smooth, and there is a presence of perforated structure (red arrow) on the membrane surface (Fig. 8b). Such alterations on the cell membrane surface are presumably caused by the involvement of cell membrane in the biosorption process of $\mathrm{Zn}^{2+}$. Moreover, several particles are present on the membrane surface (yellow arrow, Fig. 8b), indicating the formation of biosynthesized ZnO NPs. Furthermore, the existence of $\mathrm{Zn}$ absorption peak of energy dispersive X-Ray (EDX) spectrum confirms the presence of elemental $\mathrm{Zn}$. Moreover, the presence of other component peaks in the spectra is due to the chemical used for sample processing and gold biofilm during the coating process.

\section{Fourier-transform infrared (FT-IR) spectroscopy analysis}

Fourier-transform infrared (FT-IR) analysis was performed to characterize and identify the difference between functional groups of the control sample (strain TA4 without $\mathrm{Zn}^{2+}$ exposure) and zinc-exposed cell biomass that was responsible for $\mathrm{Zn}^{2+}$ biosorption. Figure 9 represents the comparative FT-IR spectra of both samples. The control sample demonstrated the presence of six major absorption peaks at 3254.1, 1635.83, 1456.3, 1403.6, 1223.69, 1078.42, and $993.79 \mathrm{~cm}^{-1}$, which shows their typical complex nature characteristics. Meanwhile, the absorption peaks of the cells exposed to $\mathrm{Zn}^{2+}$ shifted to 3273.16, 1614.88, 1423.64, 1367.59, 1221.1, and $1095.79 \mathrm{~cm}^{-1}$. Additionally, there was an absorption peak at $1550.42 \mathrm{~cm}^{-1}$ that was not seen in the control. Table 6 represents the absorption peaks of strain TA4 exposed to $\mathrm{Zn}^{2+}$ and the interpretation of vibrational assignment with functional groups. The shifted in FT-IR spectra at $3273.16 \mathrm{~cm}^{-1}$ representing $\mathrm{N}-\mathrm{H}$ asymmetric stretching of the amine and $\mathrm{O}-\mathrm{H}$ bond of hydroxyl groups on the cell surface; $1614.88 \mathrm{~cm}^{-1}(\mathrm{C}=\mathrm{O}$ stretching) and $1550.42 \mathrm{~cm}^{-1}$ (N-H bending) attributed to amide I and amide II in protein, respectively; $1423.64 \mathrm{~cm}^{-1}$ indicates $\mathrm{CH}_{3}$ bending in proteins peptide bonds; while $1367.59 \mathrm{~cm}^{-1}$ and $1221.1 \mathrm{~cm}^{-1}$ indicate $\mathrm{O}-\mathrm{H}$ bending and $\mathrm{C}-\mathrm{O}$ stretching bands of the carboxylate ion group $\left(\mathrm{COO}^{-}\right.$symmetric stretching) with phosphate groups $\left(\mathrm{P}=\mathrm{O}\right.$ and $\mathrm{P}-\mathrm{O}$ of the $\left.\mathrm{C}-\mathrm{PO}_{3}^{-2}\right)$ and $1095.79 \mathrm{~cm}^{-1}$ which corresponding to $(\mathrm{C}-\mathrm{C}=\mathrm{O}, \mathrm{C}-\mathrm{O}-\mathrm{P})$ phosphoprotein and hydroxyl groups from saccharides.

\section{Discussion}

In this study, a zinc-tolerant $L$. plantarum strain TA4 was isolated from locally fermented food (tapai pulut) that demonstrates probiotic properties. In fact, the previous study reported the presence of $\mathrm{LAB}$ with probiotic potential from tapai pulut, which is identified as L. fermentum [28]. In particular, Lactobacillus is a Gram-positive, rodshaped bacteria that is known to predominate probiotics. Notably, its presence maintains the microflora in the gut ecosystem and provides health benefits [10]. Besides that, most lactobacilli species are generally regarded as safe (GRAS) and deemed to be non-pathogenic because they are not associated with any diseases. Probiotic attributes are determined by several factors; acid and bile tolerance, hydrophobicity and aggregation ability, as well as health-promoting (antimicrobial and antioxidant) benefits [10]. As the probiotic bacteria pass through GIT, they encounter harsh conditions such as acidic and bile salts (stresses conditions) before they can colonize the small intestine. As shown in Table 2, most of the LAB strains (after $4 \mathrm{~h}$ of exposure) in this study demonstrated 

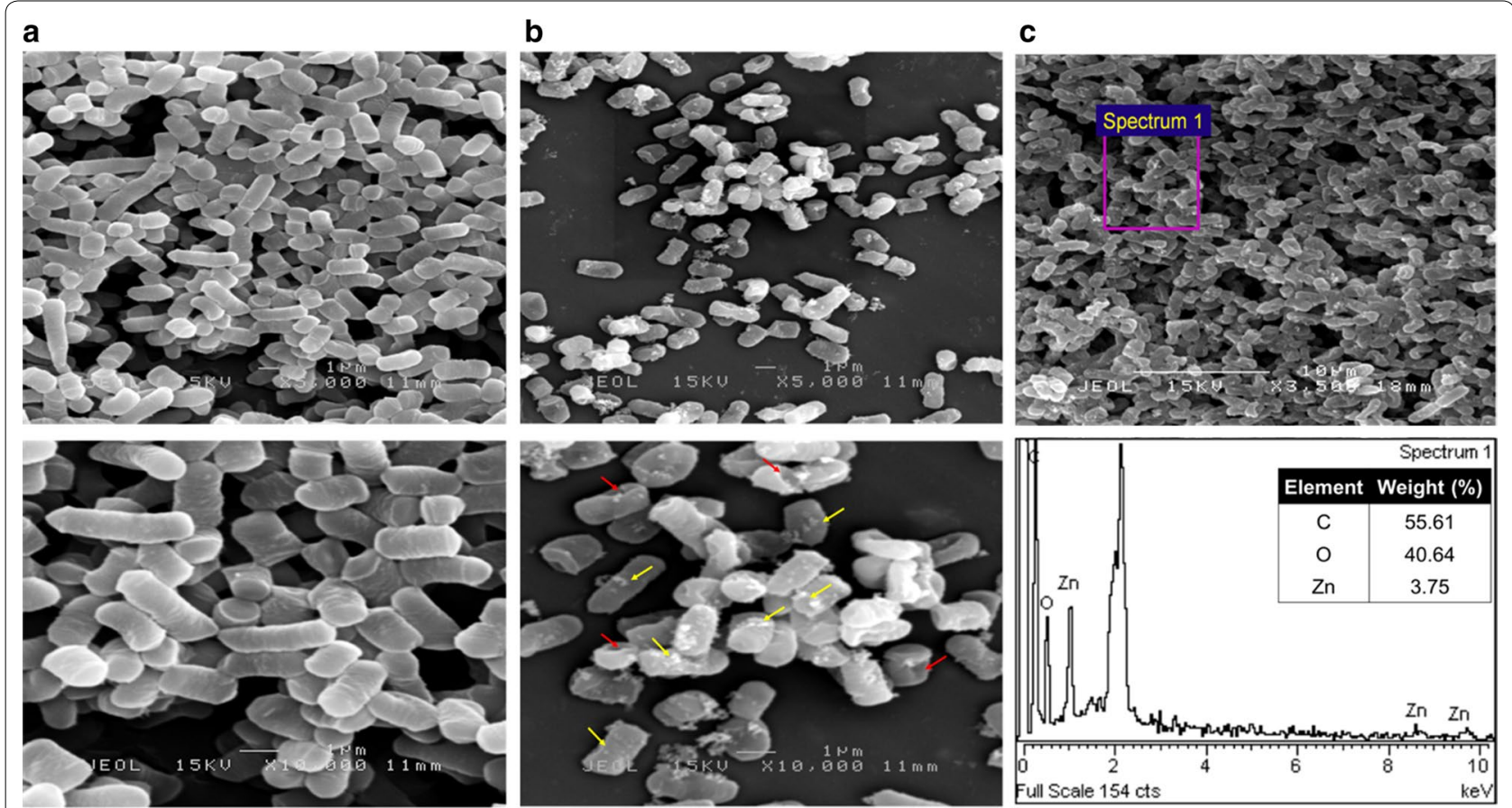

Fig. 8 SEM micrographs of L. plantarum strain TA4. Control group (unexposed to $\mathrm{Zn}^{2+}$ ) (a), Treatment group (exposed to $\mathrm{Zn}^{2+}$ ) (b), EDX spectra of $L$. plantarum strain TA4 exposed to $\mathrm{Zn}^{2+}$ (c). Electron-dense NPs are located extracellularly as indicated by yellow arrow

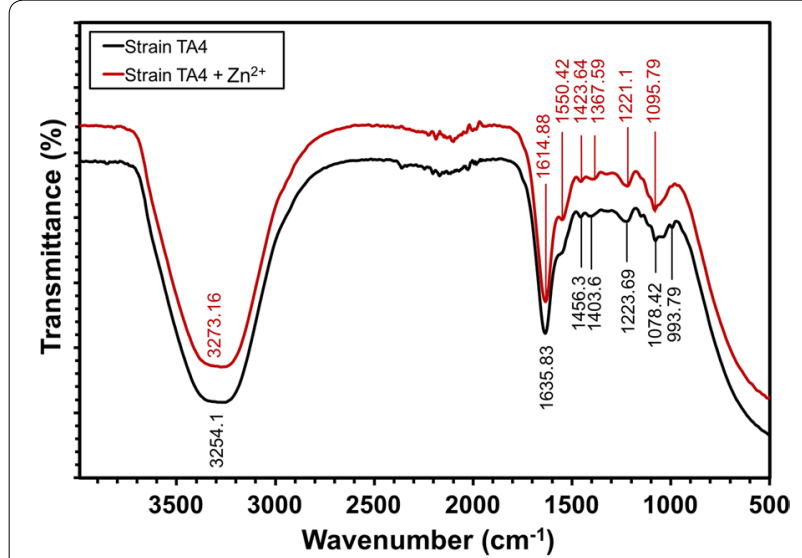

Fig. 9 Comparison of FT-IR spectral analysis of L. plantarum strain TA4 (c). The black vibrational lines indicate the control of cell biomass (unexposed to $\mathrm{Zn}^{2+}$ ) and the red line indicate the cell biomass exposed to $\mathrm{Zn}^{2+}$

high survival rate under the following conditions, specifically at $\mathrm{pH} 2.5$ and $\mathrm{pH} 3.5$ and bile concentrations of $0.3 \%$ and $0.6 \%$. These results indicate the strain robustness in resisting the challenge, which was in line with the reported results of a prior study by Giri et al. [29] where L. plantarum L7 were found to survive and retain their viability under similar conditions, specifically at $\mathrm{pH} 2$ and
$\mathrm{pH} 3$ and bile concentration of $0.3 \%$. Besides that, all LAB strains in this study demonstrated tolerance towards phenol at bile concentrations of $0.2 \%$ and $0.5 \%$. The growth of bacterium was also found unaffected after $24 \mathrm{~h}$, which demonstrated the ability of this strain to withstand the phenolic stress conditions. Phenol is known as a toxic metabolite that is produced from deamination of various amino acids by gut microorganisms derived from dietary based-protein, which exerts bacteriostatic effects on gut microbiota [30].

The probiotic adherence ability on epithelial cells is important for health-promoting effects, which is required to maintain their intestinal colonization, besides facilitating the augmentation of intestinal mucosal barrier. Therefore, this will prevent cells from the adherence of pathogenic bacteria [31], thus increase the immunity of the organism. It was reported that the hydrophobicity and autoaggregation ability of the probiotic is associated with adherence ability, which is used as an indicator to evaluate bacterial adhesion ability [32]. The obtained results revealed that the $\mathrm{LAB}$ strains showed varying degrees of hydrophobicity to toluene, which ranged from 11.4 to $58.0 \%$. In particular, the TA4 strain recorded the highest value. Hydrophobicity of above $50 \%$ is deemed acceptable for probiotics. Rondon et al. [33] reported similar results where L. salivarius strain C65 isolated from broiler chicken recorded hydrophobicity of $55.03 \%$. 
Table 6 Main absorption peaks and vibrational assignment with functional groups interpretation of $L$. plantarum strain TA4 exposed with $\mathrm{Zn}^{2+}$

\begin{tabular}{llll}
\hline Absorption peak $\left(\mathbf{c m}^{-\mathbf{1}}\right)$ & Vibrational assignment & Functional group & References \\
\hline 3273.16 & $\mathrm{O}-\mathrm{H}$ stretching and $\mathrm{N}-\mathrm{H}$ asymmetric stretching & Amine and hydroxyl & {$[75]$} \\
1614.88 & $\mathrm{C}=\mathrm{O}$ stretching & Amide I & {$[45]$} \\
1550.42 & $\mathrm{~N}-\mathrm{H}$ bending & Amide Il & {$[45]$} \\
1423.64 & $\mathrm{CH}_{2} / \mathrm{CH}_{3}$ bending & Lipids and proteins peptide & {$[76]$} \\
1367.59 & $\mathrm{C}=\mathrm{O}$ of COO${ }^{-}$symmetric stretching & Carboxylate & {$[19]$} \\
1221.1 & $\mathrm{P}=\mathrm{O} . \mathrm{P}-\mathrm{O}$ & Phosphate & {$[45]$} \\
1095.79 & $\mathrm{C}-\mathrm{C}=\mathrm{O}, \mathrm{C}-\mathrm{O}-\mathrm{P}$ & Hydroxyl from saccharides, phosphoprotein & {$[74,77]$} \\
\hline
\end{tabular}

The variation in cell hydrophobicity occurs due to the presence of different cell wall constituents, such as phosphate, carboxylate groups, and proteins, which influence the surface hydrophobicity [32]. Additionally, high autoaggregation ability of TA4 strain after incubation for $4 \mathrm{~h}$ in this study increased throughout the 24-h period, which was also observed in other strains. Angmo et al. [34] reported a similar trend where the autoaggregation activity of $L$. plantarum strains in the study increased as the incubation time increased. It is plausible due to the presence of proteins and polysaccharides on the cell surfaces that enable them to aggregate [35].

Meanwhile, the non-neutralized cell-free supernatant (CFS) of TA4 strain demonstrated antagonistic activity against the tested pathogens. However, the neutralized CFS did not show any inhibitory activity against the same pathogens. These results demonstrated the influence of the organic acid produced (based on the final $\mathrm{pH}$ ) on the inhibitory activity and that this strain is not a bacteriocin producer. Similarly, Hwanhlem et al. [36] reported no presence of bacteriocin-producing strains and that the $\mathrm{pH}$ reduction by organic acids led to the antibacterial activity of isolated $L$. plantarum from fermented shrimp (Kung-Som). The antimicrobial effects of LAB are attributed to the production of inhibitory substances, such as organic acids (such as lactic, propionic, acetic and succinic acids), hydrogen peroxide, and bacteriocins [37].

Accordingly, an excessive production of reactive oxygen species (ROS) causes cellular oxidative damage to a human body. The mechanism of probiotic antioxidant ability may be poorly understood; indeed, the antioxidant potential manifests through the chelation of metal ions, production of antioxidase, and enzyme suppression for the production of ROS [38]. DPPH is typically used to measure the antioxidant activity as it is a stable organic radical compound. In this study, the CFS of TA4 strain demonstrated greater DPPH scavenging activity at $80.5 \%$, which reaffirmed their antioxidant capability; thus, indicating their health-promoting benefits. This observation is consistent with the study of Riaz Rajoka et al. [39] that reported higher antioxidant activity of CFS of several L. rhamnosus strains, ranging from 84.0 to $88.0 \%$. Adding to that, the ability of TA4 strain to withstand metal ion in this study also explains its high antioxidant ability. Certain bacteria can adapt with high metal ion level via the formation of antioxidant enzyme superoxide dismutase (SOD) [40] that protects them from metal ion toxicity. For instance, the presence of high antioxidant enzyme when $S$. aureus was exposed to $\mathrm{Zn}^{2+}$ was said to facilitate the ability of the bacteria to cope with oxidative stress caused by metal ions [41]. Moreover, the adhesion to both chloroform (acidic, electron acceptor) and ethyl acetate (basic, electron donor) were also tested in this study to assess the cell surface Lewis acid-base characteristics of bacteria. In particular, the TA4 strain recorded high chloroform affinity at $54.9 \%$, which indicates the basic (electron donor) property of TA4 strain. The electron donor property of TA4 strain implies the strain electrostatic interactions to bind with metal cations that are associated with the presence of carboxylic $\left(-\mathrm{COO}^{-}\right)$and hydrogen sulfite $\left(-\mathrm{HSO}_{3}{ }^{-}\right)$functional groups on the bacterial surface $[21,42]$. On the other hand, the lower affinity (41.4\%) to ethyl acetate observed in this study indicates the non-acidic and poor electron acceptor properties of the TA4 strain.

Several Lactobacillus strains have been reported to resist various metals ion at different concentration levels. Most studies emphasize on bioremediation or decontamination of heavy metals in the body and environmental perspectives [19, 25, 42-48]. However, less is known about their capacity to tolerate with $\mathrm{Zn}^{2+}$ and produce zinc nanomaterials simultaneously. Zinc is an essential metal ion, however, at higher concentration, it is toxic to the bacteria [26] so bacteria evolve to protect themselves by reducing the ions to NPs. This shows that bacteria can tolerate high level of metal ions, thus act as a microbial nanofactory. Presentato et al. [49] proved that the isolated Rhodococcus aetherivorans $\mathrm{BCP} 1$ which have high tolerance toward selenium ion concentration at $500 \mathrm{mM}$ are capable to produce selenium nanoparticles 
(Se NPs). In this study, based on the PCA results, strain TA4 was chosen as a potential probiotic which exhibited the capacity to tolerate higher $\mathrm{Zn}^{2+}$ concentration at $500 \mathrm{mM}$. The results indicate the presence of highly resistant $\mathrm{LAB}$ against $\mathrm{Zn}^{2+}$ as compared to the resistant LAB studied by Leonardi et al. [50], who reported the maximum tolerance concentration (MTC) against $\mathrm{Zn}^{2+}$ of several Lactobacillus and Bifidobacterium strains at $100 \mathrm{mM}$. Moreover, former studies reported that Pseudomonas sp. SN7 and SN28 demonstrated MTC against $\mathrm{Zn}^{2+}$ at $25 \mathrm{mM}$ [51] whereas Sphinomonas sp. strain DX-T3-03 isolated from a copper mine tailing exhibited resistance to $\mathrm{Zn}^{2+}$ up to $40 \mathrm{mM}$ [52]. To our knowledge, we have reported a zinc-tolerant probiotic with the highest MTC value of $500 \mathrm{mM}$ compared to other reports in the literature. In fact, the variations in resistance against metal ions between bacterial species are due to different properties of the bacteria, which include cell wall structure, functional groups and surface area $[20,26,46]$.

To validate the formation of $\mathrm{ZnO}$ NPs by the cell biomass of strain TA4, a UV-vis spectroscopy analysis was conducted. As a result, a notable absorbance peak was obtained at $380 \mathrm{~nm}$ from the UV-vis spectroscopy, proving the formation of $\mathrm{ZnO} N P s$. This absorbance rate was due to the surface plasmon resonance (SPR) band of $\mathrm{ZnO}$ NPs. This finding was in an agreement with other studies which reported a similar absorption peak [53, 54]. According to Eltarahony et al. [54], it could be inferred that it was also due to the uniform particle size distribution. Notably, it was also proven in this DLS analysis study that the biosynthesized ZnO NPs by TA4 cells were monodispersed in nature due to the ideal PDI value obtained at 0.369 .

In this study, DLS analysis found that the average size distribution produced by TA4 strain amounted to $124.2 \pm 31.2 \mathrm{~nm}$. The average size of biosynthesized $\mathrm{ZnO}$ NPs produced by strain TA4 was within the range of biosynthesized ZnO NPs obtained through Rhodococcus pyridinivorans NT2 [55]. However, this range of size was larger than the sizes produced in other studies. Specifically, the average size of $\mathrm{ZnO}$ NPs amounted to 7-19 $\mathrm{nm}$ through L. plantarum strain in Selvarajan and Mohanasrinivasan [12], and $57.72 \mathrm{~nm}$ average size was obtained through using Aeromonas hydrophila strain in Jayaseelan et al. [56]. Essentially, small particle size is one of the main parameters which determine the physicochemical of $\mathrm{ZnO}$ NPs associated with their high surface area to volume ratio. This characteristic distinguishes them from their bulk counterparts. Nonetheless, the particle size obtained from DLS was normally larger than the average size obtained from electron microscopy method due to the effect of Brownian motion [57]. This difference of size was also due to the hydrodynamic size, where measurements were conducted based on the size of the metal core and the biological compound bound on the particle surface. As a result, an increase in particle size occurred [58]. Therefore, it is recommended that future studies conduct particle size characterization through a transmission electron microscope (TEM).

Lactic acid bacteria created exciting microorganisms which naturally possess properties which function in either intracellularly or extracellularly reducing metal ions into their respective metal NPs [5]. However, there is insufficient understanding of the actual mechanisms involved in the formation of $\mathrm{ZnO}$ NPs through LAB, Therefore, further insights on this matter are essential. This study found that the cells exposed to $\mathrm{Zn}^{2+}$ displayed pronounced structural alterations, indicating the involvement of cell membrane in the biosorption process and their function as the template for ZnO NPs biosynthesis. Furthermore, the EDX analysis of the strain TA4 cell detected a presence of zinc elemental composition, indicating the successful biosynthesis of ZnO NPs. Overall, these findings were in an agreement with previous studies on the involvement of cell membrane in the biosynthesis of selenium NPs [59], tellurium NPs [60], and gold NPs [58] by other microorganisms.

Nevertheless, Bustos et al. [61] reported that the biosynthesized NPs on living cells were not only apparent on the cell surface, but they were also present on the surrounding. It was also inferred that NPs biosynthesis by the microorganism did not only occur through adsorption (biosorption) as it could also take place through the absorption (bioaccumulation) of the metal ions and formation of NPs inside the cell. Based on TEM observations, the formation of intracellular NPs was also found in Ochrobactrum sp. strain, where the particles were found inside the cell. However, no extracellular NP was detected in SEM micrographs [59]. In this study, the depositions of extracellular $\mathrm{ZnO}$ NPs on cell surfaces were detected (refer to Fig. 8b), implying the occurrence of $\mathrm{ZnO}$ NPs biosynthesis through extracellular biotransformation by cell membrane.

The bacterial cell wall is the first component which had contact with the metal ion. It plays an important role as the barrier and binding site for the metal ion. The cell wall of LAB consists of peptidoglycans, (lipo)teichoic acids, protein, and polysaccharides [16, 21]. Meanwhile, protein is the most abundant component of the Lactobacillus cell surface. It is also known as S-layer (glycol) proteins [62], which comprise numerous functional groups such as carboxyl, hydroxyl, amine, and phosphate. These functional groups were predicted to possess various ligands and charge distributions which bound the cationic ions of $\mathrm{Zn}^{2+}$ [19]. These findings were supported by the FT-IR analysis, which identified the functional groups 
present on the cells strain TA4 involved in the biosorption and biosynthesis processes of ZnO NPs. The role of the aforementioned functional groups in $\mathrm{Zn}^{2+}$ binding process was determined by observing the shifts in their absorption peaks.

Based on Table 6, it was found that the strain TA4 cells, which were exposed to $\mathrm{Zn}^{2+}$, showed some shifts on the absorption peaks of carboxylate $(-\mathrm{COOH})$, hydroxyl $(\mathrm{O}-\mathrm{H})$, amine $(\mathrm{N}-\mathrm{H})$, and phosphate $(\mathrm{P}=\mathrm{O}, \mathrm{P}-\mathrm{O})$ functional groups compared to the control (unexposed to $\mathrm{Zn}^{2+}$ ) functional group. This finding indicated the essential role of $-\mathrm{COOH}, \mathrm{O}-\mathrm{H}, \mathrm{N}-\mathrm{H}$, and $\mathrm{P}=\mathrm{O}, \mathrm{P}-\mathrm{O}$ functional groups in $\mathrm{Zn}^{2+}$ binding process and the formation of $\mathrm{ZnO}$ NPs. These results were in an agreement with Król et al. [7] and Tripathi et al. [63], who found that the presence of peak corresponded to the carboxyl and amide groups on the $\mathrm{ZnO}$ nanocomposite and $\mathrm{ZnO}$ nanoflowers biosynthesised by L. paracasei and Bacillus licheniformis strain respectively. This biosynthesis involved the formation and stabilisation of $\mathrm{ZnO}$ NPs. In addition, the EPS secreted by L. plantarum was reported in Garmasheva et al's [15] study, where the reduction and biosorption of metal ion were involved, leading to the formation of NPs. However, this formation was contradicted with this study's finding as the TA4 strain investigated in this study did not produce EPS. Therefore, it was proven that this TA4 strain was highly dependent on its cell wall components to detoxify metal ions, including reducing and developing NPs.

Overall, some of the probiotic features of TA4 strain play a vital role in ZnO NPs biosynthesis. ZnO NPs are mainly obtained through chemical and physical methods. However, these methods involve the use of harsh chemicals, where their application would potentially result in low biocompatibility and risk to living organisms [64]. Nevertheless, microbial or biological synthesis has gained significant attention in the synthesis of $\mathrm{ZnO}$ NPs due to its eco-friendly nature, biocompatibility, and the involvement of non-toxic chemicals [5]. Despite the advantages, the primary concern in using microorganism for the biosynthesis of $\mathrm{ZnO}$ NPs is their low yield productivity, which remains a challenge. To attain the maximum yield of NPs, it is necessary to optimize the cultural conditions and various physical parameters, including temperature, $\mathrm{pH}$, precursor concentration, and reaction time [5]. It has been reported that these optimization parameters influence the yield productivity of NPs $[65,66]$; therefore, further investigation is required. Furthermore, it was found in this study that strain TA4 had the potential to function as a nanofactory, ensuring a sustainable approach for $\mathrm{ZnO}$ NPs production. It also possessed high resistance to $\mathrm{Zn}^{2+}$ as it was equipped with probiotic properties. Due to these attributes, strain TA4 possessed an advantage in its biotechnological application in the bioremediation, food, and pharmaceutical industry. Moreover, its ability to bind $\mathrm{Zn}^{2+}$ would be useful in preventing excessive dietary $\mathrm{Zn}^{2+}$ toxicity in animals and human gut [67] and in the removal of high concentration of $\mathrm{Zn}^{2+}$ from consumption of water and liquid food [20]. Notably, zinc-enriched $\mathrm{LAB}$ was reported to possess beneficial effects on living organisms [50]. This positive discovery would contribute to a new perspective regarding zinc-enriched LAB use as an organic matrix for a zinc dietary supplementation strategy for human and animals [20].

\section{Conclusion}

In conclusion, a sustainable approach for the production of $\mathrm{ZnO}$ NPs was developed using zinc-tolerant probiotic L. plantarum strain TA4, which was isolated from local fermented food. This strain was shown to possess probiotic characteristics and the strongest resistance to a high $\mathrm{Zn}^{2+}$ concentration. This was followed by the transformation of $\mathrm{Zn}^{2+}$ into $\mathrm{ZnO}$ NPs. It was proven from the SEM-EDX and FT-IR analysis used in this study that the biosynthesis of $\mathrm{ZnO}$ NPs occurred through biosorption of $\mathrm{Zn}^{2+}$ in the presence of functional groups on the cell membrane of TA4 strain. These functional groups functioned as the ligands by attracting the $\mathrm{Zn}^{2+}$ through electrostatic interaction. The $\mathrm{Zn}^{2+}$ was then reduced to $\mathrm{Zn}^{0}$ prior to its conversion to $\mathrm{ZnO}$ NPs. Furthermore, the zinc-tolerant together and the probiotic properties of strain TA4 contributed to a new possibility for the future decontamination of $\mathrm{Zn}^{2+}$ and dietary strategies. It was also indicated that an environmentally sustainable, costeffective, and biocompatible microbial cell nanofactory is essential for $\mathrm{ZnO}$ NPs production. Finally, it is recommended for future studies to characterize the physicochemical properties of the biosynthesised $\mathrm{ZnO}$ NPs production through strain TA4 and evaluate their properties for biological application.

\section{Materials and method}

\section{Preparation of zinc solution}

A $1 \mathrm{M}$ stock solution of $\mathrm{Zn}^{2+}$ was prepared by dissolving zinc sulfate $\left(\mathrm{ZnSO}_{4} \cdot 7 \mathrm{H}_{2} \mathrm{O}\right)$ in deionized water. The $\mathrm{Zn}^{2+}$ solution was sterilized by filtration and added to the bacterial culture medium.

\section{Isolation of lactic acid bacteria (LAB)}

Lactic acid bacteria was isolated from local fermented food, fruit peels, and silage using de Man, Rogosa, and Sharpe (MRS) medium. Each of the sample sources was enriched in $250 \mathrm{~mL}$ Erlenmeyer flasks containing MRS broth and incubated for $24 \mathrm{~h}$ at $37^{\circ} \mathrm{C}$ with $150 \mathrm{rpm}$ agitation. After the incubation, the bacterial culture was serially diluted, plated on MRS agar, and incubated for $24 \mathrm{~h}$ 
at $37{ }^{\circ} \mathrm{C}$. Single colonies showing different morphologies were obtained by streak plate technique. The cell morphology, Gram-stain property, and catalase reaction of all isolates were observed and recorded. Gram-positive and catalase-negative isolates were selected and stored at $-80{ }^{\circ} \mathrm{C}$ in MRS broth containing $25 \%(\mathrm{v} / \mathrm{v})$ glycerol for further processing.

\section{Determination of zinc-tolerant LAB and maximum tolerable concentration (MTC)}

Zinc-tolerant LAB was screened by inoculating the LAB strains in MRS medium containing $10 \mathrm{mM} \mathrm{Zn}^{2+}$ and incubated at $37{ }^{\circ} \mathrm{C}$ for $24 \mathrm{~h}$. LAB strains showing growth were selected for subsequent studies. To determine the MTC of LAB strains against $\mathrm{Zn}^{2+}$, the agar well diffusion method was carried out according to Hassen et al. [68] methods. $\mathrm{Zn}^{2+}$ solutions were prepared in different concentrations $(20,40,60,80,100,200,300,400,500$, and $600 \mathrm{mM}$ ). Sterile MRS agar plates were prepared and each plate was spread with overnight cultures of LAB strains. Wells were punched by a sterile borer with $6 \mathrm{~mm}$ in diameter and $100 \mu \mathrm{L}$ of $\mathrm{Zn}^{2+}$ solution of each concentration was added to each well and incubated at $37{ }^{\circ} \mathrm{C}$ for $24 \mathrm{~h}$. After incubation, the inhibition zones were recorded by measuring the distance of the edge of the zone to the edge of the well. LAB strains showing no clear zone and zone size of $1 \mathrm{~mm}$ or less were considered as resistant strains [69]. The LAB strains that showed the highest MTC value were selected for further studies. Test tube method was performed to ascertain the survivability of the strains in broth medium at different $\mathrm{Zn}^{2+}$ concentrations. The strains exhibiting the highest MTC value were grown in MRS broth containing different $\mathrm{Zn}^{2+}$ concentrations. A stock solution of $\mathrm{Zn}^{2+}$ was filter-sterilized and added in an appropriate amount with the concentration ranging from 20 to $500 \mathrm{mM}$. The culture was incubated at $37^{\circ} \mathrm{C}$ for $24 \mathrm{~h}$ and the number of cells is recorded as the average of the colony-forming unit ( $\log \mathrm{CFU} / \mathrm{mL}$ ) for each of the test tube. The experiment was performed in triplicate and mean values and standard deviations were calculated.

\section{In vitro probiotic characterization of zinc-tolerant $L A B$}

The characterization of potential probiotic LAB was screened using the following methods.

\section{Determination of $\mathrm{pH}$, bile, and phenol tolerance}

Acid and bile salt tolerance were determined according to the method describe by Ji et al. [70] with some modifications. About $1 \mathrm{~mL}$ of the overnight grown strains were transferred to $9 \mathrm{~mL}$ of fresh MRS medium adjusted to $\mathrm{pH} 2.5$ and 3.5 with $\mathrm{HCl}$ and incubated at $37{ }^{\circ} \mathrm{C}$ for $4 \mathrm{~h}$. Similarly, for bile tolerance, the strains were transferred to MRS broth containing $0.3 \%$ and $0.6 \%$ oxgall
(Oxoid, Basingstoke, UK) and incubated at $37{ }^{\circ} \mathrm{C}$ for $4 \mathrm{~h}$. The number of viable cells was determined at 0 and $4 \mathrm{~h}$ of incubation time by serially diluting the culture before plating it on MRS agar. Survival rates were determined by the number of viable cells present on the agar and calculated as colony-forming unit (CFU) per mL of sample. The survival percentage was calculated as follows:

$$
\begin{aligned}
& \text { Survival rate }(\%) \\
& \qquad \begin{array}{l}
\text { Number of initial viable cells inoculated }(\mathrm{CFU} / \mathrm{mL}) \\
\quad \times 100
\end{array}
\end{aligned}
$$

Phenol tolerance was determined by inoculating the strains in $10 \mathrm{~mL}$ MRS broth containing $0.2 \%$ and $0.5 \%$ phenol (v/v). Strains inoculated in MRS broth without phenol were used as controls. The cultures were incubated at $37{ }^{\circ} \mathrm{C}$ for $24 \mathrm{~h}$ and viable cells were counted $(\mathrm{CFU} / \mathrm{mL})$. All experiments were performed in triplicate and the mean values and standard deviations of each sample were calculated.

\section{Determination of cell surface hydrophobicity, cellular autoaggregation and exopolysaccharide (EPS) production} The hydrophobicity of the strains was evaluated by microbial adhesion to solvents (MATS) method according to Rosenberg et al. [71]. Overnight cultures were harvested by centrifugation at $5000 \mathrm{rpm}$ for $10 \mathrm{~min}$ and washed twice with PBS ( $\mathrm{pH} 7.4$ ). The harvested pellets were resuspended in the same PBS to an absorbance of 0.8 at $600 \mathrm{~nm}\left(\mathrm{~A}_{0}\right)$. Equal volumes $(1: 1)$ of solvent and suspension were mixed and vortexed thoroughly for $2 \mathrm{~min}$. The mixture was incubated at $37^{\circ} \mathrm{C}$ for $30 \mathrm{~min}$ for phase separation and the aqueous phase was spectrophotometrically measured $\left(A_{1}\right)$ at $600 \mathrm{~nm}$. Three solvents were used in this study, which were toluene (an apolar solvent), chloroform (monopolar and acidic solvent), and ethyl acetate (monopolar and basic solvent). The percentage of hydrophobicity was calculated as follows:

$$
\begin{aligned}
& \text { Hydrophobicity }(\%) \\
& \qquad \begin{array}{l}
=\frac{\left[\text { Initial optical density }\left(A_{0}\right)-\text { Final optical density }\left(A_{1}\right)\right]}{\text { Initial optical density }\left(A_{0}\right)} \\
\quad \times 100
\end{array}
\end{aligned}
$$

The autoaggregation of the strains was measured by using methods described by Giri et al. [29]. Overnight cultures were centrifuged at $5000 \mathrm{rpm}$ for $10 \mathrm{~min}$ and the pellets were washed repeatedly with PBS and resuspended in PBS (pH 7.4) to an absorbance 1.0 at $600 \mathrm{~nm}$ $\left(\mathrm{A}_{0}\right)$, vortexed for $30 \mathrm{~s}$, and incubated at $37{ }^{\circ} \mathrm{C}$ in static condition. The OD of the suspension $(1 \mathrm{~mL})$ was measured at $1\left(\mathrm{~A}_{1}\right), 4\left(\mathrm{~A}_{1}\right)$, and $24 \mathrm{~h}\left(\mathrm{~A}_{1}\right)$ at $600 \mathrm{~nm}$. The percentage of autoaggregation was calculated as follows: 


$$
\begin{aligned}
& \text { Autoaggregation }(\%) \\
& \qquad \begin{array}{l}
=\frac{\left[\text { Initial optical density }\left(A_{0}\right)-\text { Final optical density }\left(A_{1}\right)\right]}{\text { Initial optical density }\left(A_{0}\right)} \\
\quad \times 100
\end{array}
\end{aligned}
$$

The screening process for EPS production was performed according to Nambiar et al. [72] method. Briefly, each of the strain was grown on MRS agar supplemented with $5 \%$ glucose $(\mathrm{w} / \mathrm{v})$ and incubated at $37^{\circ} \mathrm{C}$ for $24-48 \mathrm{~h}$. The EPS producing-strains was identified by loop touch method to observes the ropy or mucoid features of the strains. All experiments were performed in triplicate and the mean values and standard deviations of each sample were calculated.

\section{DPPH free RSA}

The antioxidant activity (free radical-scavenging) of the LAB strains was determined according to Son and Lewis's [73] method. Overnight LAB strains were harvested by centrifugation at $5000 \mathrm{rpm}$ for $10 \mathrm{~min}$ and cell-free supernatant (CFS) were collected. Two hundred microliters of freshly prepared DPPH $(6 \mathrm{mg} / 100 \mathrm{~mL}$ methanol) was added with an equal volume of methanol-containing CFS $(10 \mu \mathrm{L}$ CFS $+190 \mu \mathrm{L}$ methanol) and thoroughly vortexed. The mixture was incubated at room temperature in the dark for $30 \mathrm{~min}$. A mixture of DPPH with methanol (1:1 volume ratio) was prepared as a control whereas methanol was used as a blank. After the incubation, the absorbance was measured at $517 \mathrm{~nm}$ using a UV spectrophotometer and the assay was performed in triplicate. The percentage of DPPH radical scavenging activity was calculated as follows:

$$
R S A_{(D P P H)}(\%)=\frac{\left(A_{\text {control }}-A_{\text {test }}\right)}{A_{\text {control }}} \times 100
$$

\section{Antibacterial activity}

The antibacterial activity of the cell-free supernatant (CFS) of LAB strains was assessed against Gram-positive and Gram-negative pathogens by agar well diffusion method. Non-neutralized CFS were prepared from overnight cultures by centrifugation (5000 rpm) and filtered, while neutralized CFS were prepared by adjusting to $\mathrm{pH} 6.5$ to 7.0 with $1 \mathrm{M} \mathrm{NaOH}$ followed by filtration. The efficacy of antibacterial activity using non-neutralized and neutralized CFS was measured by observing the inhibition zones around the well. Clear zone indicates a positive result and is expressed in millimeters. The test pathogens used were Staphylococcus aureus, Salmonella sp., Escherichia coli, and Staphylococcus epidermidis. The test was performed in triplicate.

\section{Molecular identification of zinc-tolerant probiotic LAB}

The selected strain was subjected to molecular identification. Genomic DNA was extracted using QIAamp DNA Mini Kit (Qiagen GmbH, Hilden, Germany) according to the manufacturer's instruction and amplified using universal primers 27F (5'-AGAGTTTGATCCTGGCTC AG-3') and 1492R (5'-GGTTACCTTGTTACGACT $\left.\mathrm{T}-3^{\prime}\right)$. The PCR product was purified using the QIAquick PCR Purification Kit (Qiagen, Germany) and sent for sequencing at First BASE Asia Sdn. Bhd. (Malaysia). The resulting sequence of the strain was then compared using the NCBI Basic Local Alignment Search Tool (BLAST; http://www.ncbi.nlm.nih.gov/) to search for a similar sequence in GenBank. Sequences and their closest relatives were retrieved and aligned with ClustalW. A phylogenetic tree for the nucleotide sequences was constructed using the neighbor-joining method by using MEGA software version 7 (The Biodesign Institute, Tempe, AZ, USA). Evolutionary distances of nucleotide sequences were computed using the Jukes-Cantor model (bootstrap values: 1000 resampling).

\section{Biosynthesis and extraction of ZnO NPs}

The biosynthesis of $\mathrm{ZnO}$ NPs was performed according to Markus et al. [58] method with minor modification. Briefly, L. plantarum strain TA4 was grown in MRS broth and incubated at $37{ }^{\circ} \mathrm{C}$ for $24 \mathrm{~h}$ with $150 \mathrm{rpm}$ agitation. After the incubation period, the cells were recovered by centrifugation ( $5000 \mathrm{rpm}, 20^{\circ} \mathrm{C}$ ) for $15 \mathrm{~min}$ and washed three times with PBS buffer. The cell biomass was then suspended in sterilized deionized water containing $\mathrm{Zn}^{2+}$ at concentrations of $500 \mathrm{mM}$ and incubated at $37{ }^{\circ} \mathrm{C}$ for $24 \mathrm{~h}$. After incubation, cells were collected by centrifugation at $5000 \mathrm{rpm}$ for $10 \mathrm{~min}$ and washed with saline before being suspended in buffer. To obtain the ZnO NPs, cells were disrupted by alternating cycles of ultrasonication at $100 \mathrm{~W}$ for $5 \mathrm{~min}$ and continuous centrifugation at $5000 \mathrm{rpm}$ for $5 \mathrm{~min}$. Afterwards, the $\mathrm{ZnO}$ NPs were collected by high-speed centrifugation at 13,000 rpm for $15 \mathrm{~min}$ and washed with $80 \%$ ethanol to remove any undesirable components. The $\mathrm{ZnO}$ NPs produced were collected and air-dried overnight at $60{ }^{\circ} \mathrm{C}$.

\section{Characterization of biosynthesized ZnO NPs UV-vis spectra and DLS analysis}

The formation of biosynthesized $\mathrm{ZnO}$ NPs by strain TA4 was monitored by visual assessment using UV-vis spectroscopy (Uviline 9400, Secomam, France) in a colloid solution. The spectrum was measured by observing the intense absorbance peak related to surface plasmon 
excitation in the wavelength range of 300-500 nm operated at a resolution of $1 \mathrm{~nm}$. The hydrodynamic particle size distribution and polydispersity index (PDI) of biosynthesized $\mathrm{ZnO}$ NPs in solution was measured by DLS using Nano $S$ (Malvern Instruments, UK). Briefly, about $100 \mu \mathrm{L}$ of $\mathrm{ZnO}$ NPs solution was diluted in deionized water and vortexed for homogenization before performing the measurement [74]. The measurements were carried out in triplicate, and the data obtained was in the average value generated by the software equipped with the DLS instrument. The results were presented at intensity (\%) and size number-based distributions.

\section{SEM and EDX analysis}

The morphology and elemental composition of TA4 strain exposed to $\mathrm{Zn}^{2+}$ were analyzed through SEM and EDX. The TA4 strain was grown overnight in MRS broth and incubated at $37{ }^{\circ} \mathrm{C}$ with $150 \mathrm{rpm}$ agitation. Then, cell biomass was collected by centrifugation $(5000 \mathrm{rpm}$, $10 \mathrm{~min}$ ) and washed twice with PBS buffer. The cell biomass was then suspended in $100 \mathrm{~mL}$ of sterilized deionized water containing $\mathrm{Zn}^{2+}$ at the concentration of $500 \mathrm{mM}$ in $250 \mathrm{~mL}$ flask and incubated at $37^{\circ} \mathrm{C}$ for $24 \mathrm{~h}$. After the incubation, the cells were recovered by centrifugation (5000 rpm, $10 \mathrm{~min}, 4{ }^{\circ} \mathrm{C}$ ) and were subjected to sample processing for SEM. Briefly, the samples were fixed in $2.5 \%$ glutaraldehyde for $4 \mathrm{~h}$ at $4{ }^{\circ} \mathrm{C}$ and washed thrice with $0.1 \mathrm{M}$ sodium cacodylate buffer. Afterwards, the samples were post-fixed with $1 \%$ osmium tetroxide for $2 \mathrm{~h}$ at $4{ }^{\circ} \mathrm{C}$ and washed again with the buffer for three times. The samples were dehydrated with graded acetone series (35, 50, 75, 95, and 100\%, 10 min per step) and were then critical point-dried before mounted on the stub and subsequently coated with gold film in the sputter coater. SEM observation was performed using JEOL JSM-6400. The micrographs images were recorded and processed with Adobe Photoshop. Elemental analysis of strain TA4 cells was conducted using EDX, which was carried out using SEM equipped with an EDX spectrometer.

\section{FT-IR spectroscopy analysis}

The role of functional groups in $\mathrm{Zn}^{2+}$ binding on the bacterial cell was determined by FT-IR spectra analysis according to Mrvčić et al. [19]. Briefly, the bacterial cells of strain TA4 exposed to $\mathrm{Zn}^{2+}$ for $24 \mathrm{~h}$ were prepared and centrifuged at $5000 \mathrm{rpm}$ for $20 \mathrm{~min}$ after the incubation period. The cells were washed twice with Milli- $Q$ water and dried overnight. Bacterial cells without $\mathrm{Zn}^{2+}$ exposure were prepared as control. The spectra were determined in the region of $4000-500 \mathrm{~cm}^{-1}$ at a resolution of $4 \mathrm{~cm}^{-1}$ using Nicolet 6700 (Thermo Scientific).

\section{Statistical analysis}

Data from each experiment were analyzed by one-way analysis of variance (ANOVA) and the comparison between the treatments was performed using Tukey's test with a significance level of $p<0.05$. All the statistical analyses were performed using OriginPro software (version 9; OriginLab Corporation, Northampton, MA, USA). Statistical differences among the LAB strains were analyzed through Principal component analysis (PCA) using $\mathrm{XLSTAT}_{\mathrm{TM}}$ software (Addinsoft, Paris, France). Four strains (TA4, SC8, FF2, and MPJ10) were analyzed where the discriminating variables were acid tolerance, bile tolerance, phenol tolerance, cell surface hydrophobicity (chloroform, toluene, ethyl acetate), cellular autoaggregation (1, 4, 24 h), antioxidant activity (DPPH RSA), and antimicrobial activity (E. coli, Salmonella sp., S. aureus, $S$. epidermidis).

\section{Abbreviations \\ LAB: lactic acid bacteria; ZnO NPs: zinc oxide nanoparticles; Zn: zinc; MTC: maximum tolerable concentration; DPPH: 2,2-diphenyl-1-picrylhydrazyl; RSA: radical scavenging activity; PCA: principal component analysis; DLS: dynamic light scattering; PDI: polydispersity index; SEM: scanning electron microscope; EDX: energy dispersive X-ray; FT-IR: Fourier transform infrared; TEM: transmis- sion electron microscope; CFS: cell-free supernatant.}

\section{Acknowledgements}

The authors would like to thank Universiti Putra Malaysia for the financial support given

\section{Authors' contributions}

HMY initiated the idea, the scope, designed and run the experiments. HMY performed the data analysis and wrote the manuscript. NAAR, RM, and UHZ also were involved in manuscript editing, validated the data and proofread the manuscript. All authors read and approved the final manuscript.

Funding

Not applicable.

Availability of data and materials

The datasets used and/or analyzed during the current study are available from the corresponding author on reasonable request.

Ethics approval and consent to participate

Not applicable.

Consent for publication

Not applicable.

Competing interests

The authors declare that they have no competing interests.

\footnotetext{
Author details

${ }^{1}$ Department of Bioprocess Technology, Faculty of Biotechnology and Biomolecular Sciences, Universiti Putra Malaysia, 43400 Serdang, Selangor, Malaysia. ${ }^{2}$ Department of Biochemistry, Faculty of Biotechnology and Biomolecular Sciences, Universiti Putra Malaysia, 43400 Serdang, Selangor, Malaysia. ${ }^{3}$ Bioprocessing and Biomanufacturing Research Centre, Faculty of Biotechnology and Biomolecular Sciences, Universiti Putra Malaysia, 43400 Serdang, Selangor, Malaysia.
}

Received: 15 October 2019 Accepted: 3 January 2020 Published online: 15 January 2020 


\section{References}

1. Lin Wang Z. Zinc oxide nanostructures: growth, properties and applications. J Phys Condens Matter. 2004. https://doi. org/10.1088/0953-8984/16/25/R01.

2. Jiang J, Pi J, Cai J. The advancing of zinc oxide nanoparticles for biomedical applications. Bioinorg Chem Appl. 2018. https://doi. org/10.1155/2018/1062562

3. Smijs TG, Pavel S. Titanium dioxide and zinc oxide nanoparticles in sunscreens: focus on their safety and effectiveness. Nanotechnol Sci Appl. 2011. https://doi.org/10.2147/NSA.S19419.

4. Ong CB, Ng LY, Mohammad AW. A review of $\mathrm{ZnO}$ nanoparticles as solar photocatalysts: synthesis, mechanisms and applications. Renew Sustain Energy Rev. 2018;81:536-51. https://doi.org/10.1016/j.rser.2017.08.020.

5. Mohd Yusof H, Mohamad R, Zaidan UH, Abdul Rahman NA. Microbial synthesis of zinc oxide nanoparticles and their potential application as an antimicrobial agent and a feed supplement in animal industry: a review. J Anim Sci Biotechnol. 2019;10:1-22. https://doi.org/10.1186/s40104-019-0368-z.

6. Kolodziejczak-Radzimska A, Jesionowski T. Zinc oxide-from synthesis to application: a review. Materials. 2014. https://doi.org/10.3390/ma704 2833.

7. Król A, Railean-Plugaru V, Pomastowski P, Złoch M, Buszewski B. Mechanism study of intracellular zinc oxide nanocomposites formation. Colloids Surf A Physicochem Eng Asp. 2018;553:349-58. https://doi.org/10.1016/j. colsurfa.2018.05.069.

8. Jain N, Bhargava A, Tarafdar JC, Singh SK, Panwar J. A biomimetic approach towards synthesis of zinc oxide nanoparticles. Appl Microbiol Biotechnol. 2013;97:859-69. https://doi.org/10.1007/s00253-012-3934-2.

9. Chauhan R, Reddy A, Abraham J. Biosynthesis of silver and zinc oxide nanoparticles using Pichia fermentans JA2 and their antimicrobial property. Appl Nanosci. 2015;5:63-71. https://doi.org/10.1007/s1320 4-014-0292-7.

10. George Kerry R, Patra JK, Gouda S, Park Y, Shin HS, Das G. Benefaction of probiotics for human health: a review. J Food Drug Anal. 2018. https://doi. org/10.1016/j.jfda.2018.01.002.

11. Al-Zahrani H, El-Waseif A, El-Ghwas D. Biosynthesis and evaluation of TiO2 and $\mathrm{ZnO}$ nanoparticles from in vitro stimulation of Lactobacillus johnsonii. J Innov Pharm Biol Sci. 2018;5:16-20.

12. Selvarajan E, Mohanasrinivasan V. Biosynthesis and characterization of ZnO nanoparticles using Lactobacillus plantarum VITES07. Mater Lett. 2013;112:180-2. https://doi.org/10.1016/j.matlet.2013.09.020.

13. Moreno-Martin G, Pescuma M, Pérez-Corona T, Mozzi F, Madrid Y. Determination of size and mass-and number-based concentration of biogenic SeNPs synthesized by lactic acid bacteria by using a multimethod approach. Anal Chim Acta. 2017. https://doi.org/10.1016/j.aca.2017.09.033.

14. Nair B, Pradeep T. Coalescence of nanoclusters and formation of submicron crystallites assisted by Lactobacillus strains. Cryst Growth Des. 2002. https://doi.org/10.1021/cg0255164.

15. Garmasheva I, Kovalenko N, Voychuk S, Ostapchuk A, Livins'ka O, Oleschenko L. Lactobacillus species mediated synthesis of silver nanoparticles and their antibacterial activity against opportunistic pathogens in vitro. Biolmpacts. 2016. https://doi.org/10.15171/bi.2016.29.

16. Chapot-Chartier MP, Kulakauskas S. Cell wall structure and function in lactic acid bacteria. Microb Cell Fact. 2014. https://doi. org/10.1186/1475-2859-13-S1-S9.

17. Ruas-Madiedo P, Hugenholtz J, Zoon P. An overview of the functionality of exopolysaccharides produced by lactic acid bacteria. Int Dairy J. 2002 https://doi.org/10.1016/S0958-6946(01)00160-1.

18. Küsel K. Microbial cycling of iron and sulfur in acidic coal mining lake sediments. Water Air Soil Pollut Focus. 2003. https://doi.org/10.1023/a:10221 03419928.

19. Mrvčić J, Prebeg T, Barišić L, Stanzer D, Bačun-Drùina V, Stehlik-Tomas $\checkmark$. Zinc binding by lactic acid bacteria. Food Technol Biotechnol. 2009;47:381-8.

20. Mrvčić J, Stanzer D, Šolić E, Stehlik-Tomas V. Interaction of lactic acid bacteria with metal ions: opportunities for improving food safety and quality. World J Microbiol Biotechnol. 2012. https://doi.org/10.1007/s1127 4-012-1094-2.

21. Sintubin L, De Windt W, Dick J, Mast J, Van Der Ha D, Verstraete W, et al. Lactic acid bacteria as reducing and capping agent for the fast and efficient production of silver nanoparticles. Appl Microbiol Biotechnol. 2009. https://doi.org/10.1007/s00253-009-2032-6.
22. Tiquia-Arashiro SM. Lead absorption mechanisms in bacteria as strategies for lead bioremediation. Appl Microbiol Biotechnol. 2018. https://doi. org/10.1007/s00253-018-8969-6.

23. Giller KE, Witter E, McGrath SP. Heavy metals and soil microbes. Soil Biol Biochem. 2009;41:2031-7. https://doi.org/10.1016/j.soilbio.2009.04.026.

24. Mrvčić J, Butorac A, Šolić E, Stanzer D, Bačun-Družina V, Cindrić M, et al. Characterization of Lactobacillus brevis L62 strain, highly tolerant to copper ions. World J Microbiol Biotechnol. 2013. https://doi.org/10.1007/ s11274-012-1160-9.

25. Halttunen T, Finell M, Salminen S. Arsenic removal by native and chemically modified lactic acid bacteria. Int J Food Microbiol. 2007. https://doi. org/10.1016/j.jifoodmicro.2007.06.002.

26. Choudhury R, Srivastava S. Zinc resistance mechanisms in bacteria. Curr Sci. 2001;81:768-75.

27. Bhargava A, Jain N, Khan MA, Pareek V, Dilip RV, Panwar J. Utilizing metal tolerance potential of soil fungus for efficient synthesis of gold nanoparticles with superior catalytic activity for degradation of rhodamine B. J Environ Manag. 2016;183:22-32. https://doi.org/10.1016/j.jenvm an.2016.08.021

28. Khalil ES, Manap MY, Mustafa S, Amid M, Alhelli AM, Aljoubori A. Probiotic characteristics of exopolysaccharides-producing lactobacillus isolated from some traditional Malaysian fermented foods. CYTA J Food. 2018. https://doi.org/10.1080/19476337.2017.1401007.

29. Giri SS, Sen SS, Saha S, Sukumaran V, Park SC. Use of a potential probiotic, Lactobacillus plantarum $\mathrm{L} 7$, for the preparation of a rice-based fermented beverage. Front Microbiol. 2018. https://doi.org/10.3389/fmicb .2018.00473.

30. Palaniswamy SK, Govindaswamy V. In-vitro probiotic characteristics assessment of feruloyl esterase and glutamate decarboxylase producing Lactobacillus spp. isolated from traditional fermented millet porridge (kambu koozh). LWT Food Sci Technol. 2016. https://doi.org/10.1016/j. Iwt.2015.12.024.

31. Honey Chandran C, Keerthi TR. Probiotic potency of Lactobacillus plantarum KX519413 and KX519414 isolated from honey bee gut. FEMS Microbiol Lett. 2018. https://doi.org/10.1093/femsle/fnx285.

32. Tang W, Li C, He Z, Pan F, Pan S, Wang Y. Probiotic properties and cellular antioxidant activity of Lactobacillus plantarum MA2 isolated from Tibetan Kefir grains. Probiotics Antimicrob Proteins. 2018. https://doi.org/10.1007/ s12602-017-9349-8

33. Rondon AJ, Samaniego LM, Bocourt R, Rodriguez S, Milian G, Ranilla MJ, et al. Isolation, identification and partial characterization of the probiotic properties of Lactobacillus sp strains obtained from the gastrointestinal tract of broilers. Cienc y Tecnol Aliment. 2008;6:56-63.

34. Angmo K, Kumari A, Savitri, Bhalla TC. Probiotic characterization of lactic acid bacteria isolated from fermented foods and beverage of Ladakh. LWT Food Sci Technol. 2016. https://doi.org/10.1016/j.lwt.2015.10.057.

35. Kumari A, Angmo K, Monika, Bhalla TC. Probiotic attributes of indigenous Lactobacillus spp. isolated from traditional fermented foods and beverages of north-western Himalayas using in vitro screening and principal component analysis. J Food Sci Technol. 2016. https://doi.org/10.1007/ s13197-016-2231-y.

36. Hwanhlem N, Watthanasakphuban N, Riebroy S, Benjakul S, H-Kittikun A, Maneerat S. Probiotic lactic acid bacteria from Kung-Som: isolation, screening, inhibition of pathogenic bacteria. Int J Food Sci Technol. 2010. https://doi.org/10.1111/j.1365-2621.2010.02172.x.

37. Vizoso Pinto MG, Franz CMAP, Schillinger U, Holzapfel WH. Lactobacillus spp. with in vitro probiotic properties from human faeces and traditional fermented products. Int J Food Microbiol. 2006. https://doi.org/10.1016/j. ijfoodmicro.2006.01.029.

38. Wang Y, Wu Y, Wang Y, Xu H, Mei X, Yu D, et al. Antioxidant properties of probiotic bacteria. Nutrients. 2017. https://doi.org/10.3390/nu9050521.

39. Riaz Rajoka MS, Mehwish HM, Siddiq M, Haobin Z, Zhu J, Yan L, et al. Identification, characterization, and probiotic potential of Lactobacillus rhamnosus isolated from human milk. LWT Food Sci Technol. 2017. https ://doi.org/10.1016/j.lwt.2017.05.055.

40. Wiesemann N, Mohr J, Grosse C, Herzberg M, Hause G, Reith F, et al. Influence of copper resistance determinants on gold transformation by cupriavidus metallidurans strain CH34. J Bacteriol. 2013. https://doi. org/10.1128/jb.01951-12

41. Chudobova D, Dostalova S, Ruttkay-Nedecky B, Guran R, Rodrigo MAM, Tmejova K, et al. The effect of metal ions on Staphylococcus aureus 
revealed by biochemical and mass spectrometric analyses. Microbiol Res. 2015. https://doi.org/10.1016/j.micres.2014.08.003.

42. Kirillova AV, Danilushkina AA, Irisov DS, Bruslik NL, Fakhrullin RF, Zakharov YA, et al. Assessment of resistance and bioremediation ability of lactobacillus strains to lead and cadmium. Int J Microbiol. 2017. https://doi. org/10.1155/2017/9869145.

43. Zhai Q, Tian F, Zhao J, Zhang H, Narbad A, Chen W. Oral administration of probiotics inhibits absorption of the heavy metal cadmium by protecting the intestinal barrier. Appl Environ Microbiol. 2016. https://doi. org/10.1128/aem.00695-16.

44. Daisley BA, Monachese M, Trinder M, Bisanz JE, Chmiel JA, Burton JP, et al. Immobilization of cadmium and lead by Lactobacillus rhamnosus GR-1 mitigates apical-to-basolateral heavy metal translocation in a Caco-2 model of the intestinal epithelium. Gut Microbes. 2018. https://doi. org/10.1080/19490976.2018.1526581.

45. Yi YJ, Lim JM, Gu S, Lee WK, Oh E, Lee SM, et al. Potential use of lactic acid bacteria Leuconostoc mesenteroides as a probiotic for the removal of $\mathrm{Pb}(\mathrm{II})$ toxicity. J Microbiol. 2017. https://doi.org/10.1007/s12275-017-6642-x.

46. Mrvc J, Ic V, Stanzer D, Bac V, Un-Družina V, Stehlik-Tomas V. Copper binding by lactic acid bacteria (LAB). Biosci Microflora. 2009;28:1-6.

47. Bhakta JN, Ohnishi K, Munekage Y, Iwasaki K, Wei MQ. Characterization of lactic acid bacteria-based probiotics as potential heavy metal sorbents. J Appl Microbiol. 2012. https://doi.org/10.1111/j.1365-2672.2012.05284.X.

48. Halttunen T, Collado MC, El-Nezami H, Meriluoto J, Salminen S. Combining strains of lactic acid bacteria may reduce their toxin and heavy metal removal efficiency from aqueous solution. Lett Appl Microbiol. 2008. https://doi.org/10.1111/j.1472-765X.2007.02276.X.

49. Presentato A, Piacenza E, Anikovskiy M, Cappelletti M, Zannoni D, Turner RJ. Biosynthesis of selenium-nanoparticles and -nanorods as a product of selenite bioconversion by the aerobic bacterium Rhodococcus aetherivorans BCP1. N Biotechnol. 2018. https://doi.org/10.1016/..nbt.2017.11.002.

50. Leonardi A, Zanoni S, De Lucia M, Amaretti A, Raimondi S, Rossi M. Zinc uptake by lactic acid bacteria. ISRN Biotechnol. 2013. https://doi. org/10.5402/2013/312917.

51. Ahemad M, Malik A. Bioaccumulation of heavy metals by zinc resistant bacteria isolated from agricultural soils irrigated with wastewater. Bacteriol J. 2012. https://doi.org/10.3923/bj.2012.12.21.

52. Xie X, Fu J, Wang H, Liu J. Heavy metal resistance by two bacteria strains isolated from a copper mine tailing in China. Afr J Biotechnol. 2010;9:4056-66.

53. Ogunyemi SO, Abdallah Y, Zhang M, Fouad H, Hong X, Ibrahim E, et al. Green synthesis of zinc oxide nanoparticles using different plant extracts and their antibacterial activity against Xanthomonas oryzae pv. oryzae. Artif Cells Nanomed Biotechnol. 2019. https://doi.org/10.1080/21691 401.2018.1557671.

54. Eltarahony M, Zaki S, Elkady M, Abd-El-Haleem D. Biosynthesis, characterization of some combined nanoparticles, and its biocide potency against a broad spectrum of pathogens. J Nanomater. 2018. https://doi. org/10.1155/2018/5263814.

55. Kundu D, Hazra C, Chatterjee A, Chaudhari A, Mishra S. Extracellular biosynthesis of zinc oxide nanoparticles using Rhodococcus pyridinivorans NT2: multifunctional textile finishing, biosafety evaluation and in vitro drug delivery in colon carcinoma. J Photochem Photobiol B Biol. 2014;140:194-204. https://doi.org/10.1016/j.jphotobiol.2014.08.001.

56. Jayaseelan C, Rahuman AA, Kirthi AV, Marimuthu S, Santhoshkumar T, Bagavan A, et al. Novel microbial route to synthesize $\mathrm{ZnO}$ nanoparticles using Aeromonas hydrophila and their activity against pathogenic bacteria and fungi. Spectrochim Acta A Mol Biomol Spectrosc. 2012;90:78-84. https://doi.org/10.1016/j.saa.2012.01.006

57. Zhang XF, Liu ZG, Shen W, Gurunathan S. Silver nanoparticles: synthesis, characterization, properties, applications, and therapeutic approaches. Int J Mol Sci. 2016. https://doi.org/10.3390/ijms17091534.

58. Markus J, Mathiyalagan R, Kim YJ, Abbai R, Singh P, Ahn S, et al. Intracellular synthesis of gold nanoparticles with antioxidant activity by probiotic Lactobacillus kimchicus DCY51T isolated from Korean kimchi. Enzyme Microb Technol. 2016;95:85-93. https://doi.org/10.1016/j. enzmictec.2016.08.018.

59. Zonaro E, Piacenza E, Presentato A, Monti F, Dell'Anna R, Lampis S, et al. Ochrobactrum sp. MPV1 from a dump of roasted pyrites can be exploited as bacterial catalyst for the biogenesis of selenium and tellurium nanoparticles. Microb Cell Fact. 2017. https://doi.org/10.1186/ s12934-017-0826-2.

60. Liang X, Perez MAM-J, Nwoko KC, Egbers P, Feldmann J, Csetenyi L, et al. Fungal formation of selenium and tellurium nanoparticles. Appl Microbiol Biotechnol. 2019. https://doi.org/10.1007/s00253-019-09995-6.

61. Bustos MC, Ibarra H, Dussán J. The golden activity of Lysinibacillus sphaericus: new insights on gold accumulation and possible nanoparticles biosynthesis. Materials. 2018. https://doi.org/10.3390/ma11091587.

62. Frece J, Kos B, Svetec IK, Zgaga Z, Mrša V, Šušković J. Importance of S-layer proteins in probiotic activity of Lactobacillus acidophilus M92. J Appl Microbiol. 2005. https://doi.org/10.1111/j.1365-2672.2004.02473.x.

63. Tripathi RM, Bhadwal AS, Gupta RK, Singh P, Shrivastav A, Shrivastav BR. $\mathrm{ZnO}$ nanoflowers: novel biogenic synthesis and enhanced photocatalytic activity. J Photochem Photobiol B Biol. 2014;141:288-95. https://doi. org/10.1016/j.jphotobiol.2014.10.001.

64. Agarwal H, Menon S, Venkat Kumar S, Rajeshkumar S. Mechanistic study on antibacterial action of zinc oxide nanoparticles synthesized using green route. Chem Biol Interact. 2018;286:60-70. https://doi. org/10.1016/j.cbi.2018.03.008.

65. Korbekandi H, Iravani S, Abbasi S. Optimization of biological synthesis of silver nanoparticles using Lactobacillus casei subsp. casei. J Chem Technol Biotechnol. 2012;87:932-7. https://doi.org/10.1002/jctb.3702.

66. Saxena J, Sharma PK, Sharma MM, Singh A, Fu Y, Mathew J, et al. Process optimization for green synthesis of silver nanoparticles by Sclerotinia sclerotiorum MTCC 8785 and evaluation of its antibacterial properties. SpringerPlus. 2016;5(1):861.

67. Le B, Yang SH. Biosorption of cadmium by potential probiotic Pediococcus pentosaceus using in vitro digestion model. Biotechnol Appl Biochem. 2019. https://doi.org/10.1002/bab.1783.

68. Hassen A, Saidi N, Cherif M, Boudabous A. Resistance of environmental bacteria to heavy metals. Bioresour Technol. 1998. https://doi. org/10.1016/S0960-8524(97)00161-2.

69. Johncy Rani M, Hemambika B, Hemapriya J, Rajesh Kannan V. Comparative assessment of heavy metal removal by immobilized and dead bacterial cells: a biosorption approach. Afr J Environ Sci Technol. 2010. https:// doi.org/10.5897/AJEST09.184.

70. Ji K, Jang NY, Kim YT. Isolation of lactic acid bacteria showing antioxidative and probiotic activities from kimchi and infant feces. J Microbiol Biotechnol. 2015. https://doi.org/10.4014/jmb.1501.01077.

71. Rosenberg M, Gutnick D, Rosenberg E. Adherence of bacteria to hydrocarbons: a simple method for measuring cell-surface hydrophobicity. FEMS Microbiol Lett. 1980. https://doi.org/10.1111/j.1574-6968.1980.tb05599.x.

72. Nambiar RB, Sellamuthu PS, Perumal AB, Sadiku ER, Phiri G, Jayaramudu J. Characterization of an exopolysaccharide produced by Lactobacillus plantarum HM47 isolated from human breast milk. Process Biochem. 2018. https://doi.org/10.1016/j.procbio.2018.07.018.

73. Son S, Lewis BA. Free radical scavenging and antioxidative activity of caffeic acid amide and ester analogues: structure-activity relationship. J Agric Food Chem. 2002. https://doi.org/10.1021/jf010830b.

74. Li J, Li Q, Ma X, Tian B, Li T, Yu J, et al. Biosynthesis of gold nanoparticles by the extreme bacterium Deinococcus radiodurans and an evaluation of their antibacterial properties. Int J Nanomed. 2016. https://doi. org/10.2147/IJN.S119618.

75. Afzal AM, Rasool MH, Waseem M, Aslam B. Assessment of heavy metal tolerance and biosorptive potential of Klebsiella variicola isolated from industrial effluents. AMB Express. 2017. https://doi.org/10.1186/s13568-017-0482-2.

76. Tan L, Dong H, Liu X, He J, Xu H, Xie J. Mechanism of palladium(II) biosorption by: Providencia vermicola. RSC Adv. 2017. https://doi. org/10.1039/c6ra27589c.

77. David M, Krishna PM, Sangeetha J. Elucidation of impact of heavy metal pollution on soil bacterial growth and extracellular polymeric substances flexibility. 3 Biotech. 2016. https://doi.org/10.1007/s13205-016-0475-x.

\section{Publisher's Note}

Springer Nature remains neutral with regard to jurisdictional claims in published maps and institutional affiliations. 